\title{
PREPOZYTURA KANONIKÓW REGULARNYCH LATERAŃSKICH W KRASNEM NA MAZOWSZU (1681-1819), FUNDACJI KRASIŃSKICH HERBU ŚLEPOWRON
}

\section{Wstęp}

Prepozytura kanoników regularnych laterańskich w Krasnem na Mazowszu, w ziemi ciechanowskiej - rodowym gnieździe rodu Krasińskich herbu Ślepowron, została utworzona w 1681 r. Kościół będący siedzibą prepozytury, którego początki sięgają XIV w., został przebudowany przez Jana Kazimierza Krasińskiego, który rozpoczął starania, aby uczynić z niego prepozyturę opactwa czerwińskiego kanoników regularnych laterańskich oraz przez Jana Dobrogosta Krasińskiego, który uskutecznił zabiegi ojca, dając początek prepozyturze. Prepozytura funkcjonowała do 1819 r., kiedy to uległo kasacie opactwo czerwińskie.

Kościół w Krasnem doczekał się kilku opracowań począwszy od XIX w. pisali o nim: Hipolit Gawarecki ${ }^{1}$, Stanisław Karwowski, a w XX i XXI w. Izabella Galicka i Hanna Sygietyńska², Witold Masiak $^{3}$, Ferdynand Łydyński ${ }^{4}$, oraz ostatnio Łukasz Paweł Młynarski ${ }^{5}$. Jednak żadna $\mathrm{z}$ tych prac nie pogłębia zagadnienia prepozytury kanoników regularnych, ograniczając się do zaledwie kilku zdań dotyczą-

${ }^{1}$ H. G a w a r e c k i, Pamiętnik historyczny płocki, t. 2. Warszawa 1830.

${ }^{2}$ I. G a li c ka, H. Sy g i e tyń s k a, Ciechanów $i$ okolice, [w:] Katalog zabytków sztuki $w$ Polsce, t. 10, [Województwo warszawskie], z. 1, Warszawa: Instytut Sztuki PAN, 1977, s. 21-22.

${ }^{3}$ W. M a s i a k, Krasne-Krasińscy-Opinogóra, Warszawa 1975.

${ }^{4}$ F. Ł y d y ń s k i, Dzieje kościoła w Krasnem, „Mazowsze”, 7/(I/96) s. 25.

${ }^{5}$ Ł. P. Mły nars ki, Kościół i mauzoleum Krasińskich $w$ Krasnem $w$ okresie nowożytnym. Przyczynek do dziejów obiektu, [w:] Franciszka z Krasińskich Wettyn, red. D. K a l i n a, R. K u b i c k i, M. W a r d z y ń s k i, Kielce-Lisów 2012, s. 56.

„Nasza Przeszłość” t. 132: 2019, s. 181-218. 
cych tego tematu. Dysponujemy stosunkowo bogatym materiałem archiwalnym dotyczącym funkcjonowania parafii w Krasnem, obecnie przechowywanym w Archiwum Diecezjalnym w Płocku, jednak są to materiały dotyczące okresu od XVIII w., z wieku XVII zachowały się jedynie Księgi Metrykalne. Archiwalia te, wykorzystywane przez wszystkich autorów wymienionych powyżej, nastręczają pewnych problemów związanych $\mathrm{z}$ interpretacją informacji $\mathrm{w}$ nich zawartych. Kontrowersje budzi zwłaszcza trzykrotna konsekracja kościoła w Krasnem oraz autorstwo projektu kościoła i plebani kanoników.

\section{Kanonicy regularni laterańscy w Krasnem}

Jan Kazimierz Krasiński (1607-1669), podskarbi koronny, wojewoda płocki, starosta opinogórski dążył do obsadzenia kościoła kraśnieńskiego kanonikami regularnymi z Czerwińska. Parafia kraśnieńska istniejąca od XV w., była prowadzona przez księży diecezjalnych. Dążenie do obsadzenia kościoła w Krasnem zakonnikami wynikało z przekonania o niskim poziomie moralnym i intelektualnym kleru diecezjalnego $^{6}$. Jak pisze ks. Wojciech Góralski o diecezji płockiej w tym okresie: ,(...) nie znaleźli tutaj pola działania protestanci ani żydzi (...) Bolączką diecezji pozostawał niski poziom wikariuszy parafialnych, zaniedbywanie rezydencji przez członków kapituł, kapłani wędrowni (...)"7. Wiesław Muller pisze o relacji biskupa Wojciecha Baranowskiego: „(...) wikarzy są w większości ciemni, niewykształceni, oddają się pijaństwu i rozpuście (...). Tę swoją ujemną opinię o wikarych rozszerzył Baranowski w relacji z 1598 r. również na plebanów wiejskich informując, że ujemnymi cechami (...) diecezji płockiej jest lenistwo, pijaństwo, (...) jak również brak pilności w studiowaniu i douczaniu się (...)"8. Krasińscy chcąc zapewnić wysoki poziom opieki duszpasterskiej dążyli do obsadzania kościołów w swoich dobrach zakonnikami. Nie tylko zabiegali o sprowadzenie

\footnotetext{
${ }^{6}$ W. J. Gó r c z y k, Reformaci $w$ Węgrowie. Architektura kościoła i miejsce fundacji węgrowskiej na tle działalności fundacyjnej Krasińskich, „Drohiczyński Przegląd Naukowy", nr 10 (2018), s. 307- 326.

${ }^{7}$ W. G ó r a l s k i, Diecezja płocka i jej synody w okresie potrydenckim, ,Studia Płockie”, t. 14 (1986), s. 166.

${ }^{8}$ A. Mull e r, Diecezja płocka od drugiej połowy XVI wieku do rozbiorów, „Studia Płockie" 3 (1975), s. 168.
} 
kanoników regularnych do Krasnego, ale także w Węgrowie powierzyli duszpasterstwo zakonnikom, reformatom i bartolomitom ${ }^{9}$. Inicjatywa Jana Kazimierza, by powierzyć duszpasterstwo w Krasnem kanonikom regularnym, została zablokowana przez biskupa płockiego Jana Gembickiego i ówczesnego proboszcza kraśnieńskiego Marcina Łączyńskiego $^{10}$. Biskupi płoccy mieli złą opinię na temat opactwa czerwińskiego $^{11}$, najwyraźniej tej opinii nie podzielali Krasińscy. Warto podkreślić,_że ordynariusze diecezji płockiej w ogóle mieli tendencję do złej oceny zakonów we własnej diecezji, nie zawsze słusznej. Można tutaj wspomnieć o biskupie Andrzeju Chryzostomie Załuskim, który w 1696 r. przesłał swoją relację do Rzymu, w której to większość zakonów w diecezji płockiej jest oceniona negatywnie. Można przypuszczać, że ta ocena jest skutkiem chęci rozciągnięcia swojej władzy nad klasztorami, nawet tymi, które cieszyły się egzempcją, co doprowadziło do otwartego konfliktu biskupa Załuskiego z norbertankami płockimi.

Dopiero Janowi Dobrogostowi Krasińskiemu w 1681 r. udało się zrealizować zamiar swojego ojca i oddać kościół kanonikom regularnym laterańskim z Czerwińska ${ }^{12}$. Odbyło się to za zgodą biskupa płockiego Bonawentury Madalińskiego ${ }^{13}$. Opat czerwiński Andrzej z Leszna Leszczyński wyraził zgodę na objęcie przez podległych mu zakonników kościoła parafialnego w Krasnem jako prepozytury czerwińskiej. Po śmierci dotychczasowego proboszcza w Krasnem Marcina Łączyńskiego, biskup Madaliński instytuował 22 stycznia 1681 r. kanonika regularnego z Czerwińska ks. Franciszka Józefa Jagodkowicza, który został pierwszym prepozytem krasnieńskim z zakonu kanoników regularnych opactwa czerwińskiego ${ }^{14}$. Oficjalne zatwierdzenie parafii w Krasnem jako prepozytury opactwa czerwińskiego przez papieża Klemensa XI nastąpiło w $1701 \mathrm{r}^{15}$.

\footnotetext{
9 W. J. G ó r c z y k, Kościót reformatów w Wegrowie fundacji wojewody płockiego, starosty przasnyskiego, Jana Dobrogosta Krasińskiego herbu Ślepowron, „Notatki Płockie", nr 1 (2018), s. 13-21.

${ }^{10}$ F. Ły d y ń s k i, dz. cyt., s. 25.

${ }^{11}$ ADP, Acta episcopalia, 46, k. 505.

12 Niekiedy za „Korespondentem Płockim” jest podawana błędna data 1682 r. „Korespondent Płocki”, 10 czerwca 1886, s. 1.

${ }^{13}$ F. Ł y d yń s k i, dz. cyt., s. 25.

${ }^{14}$ H. F o 1 w a r s k i, Poczet opatów klasztoru kanoników regularnych $w$ Czerwińsku, „Nasza Przeszłość", t. 6 (1959) s. 38.

15 ADP, Akta wizytacji archidiakonatu płockiego z 1598-1599 r., syg. 5, k. 200.
} 
W 1689 r. przy prepozyturze w Krasnem erygowano bractwa Matki Boskiej Szkaplerznej i Matki Boskiej Różańcowej, z tej okazji ufundowano także obraz Matki Boskiej Szkaplerznej. Bractwa w okresie potrydenckim były podporządkowane bezpośrednio Stolicy Apostolskiej i ordynariuszowi miejsca. Erekcja bractw była zgodna z barokowym modelem pobożności. Msze trydenckie przybierały bardziej kwieciste formy, a godną oprawę zapewniały nie tylko bogato zdobione szaty liturgiczne, ale też pełna przepychu architektura i rozbudowana oprawa muzyczna. Podobnie było w Krasnem, gdzie wraz z prepozyturą Krasińscy zapewnili uposażenie dla organisty i siedmiu muzyków, ufundowali organy i wystawili chór muzyczny. Oprócz mszy św. odprawiano liczne nabożeństwa, otaczano kultem relikwie i obrazy. W kraśnieńskim kościele, oprócz obrazów ufundowanych dla bractw, otoczony kultem był obraz stygmatyzacji św. Franciszka z Asyżu, dla którego w 1694 r. prepozyt Jagodkowicz ufundował złotą sukienkę. Z kościoła czerwińskiego kanonicy przenieśli do kościoła w Krasnem obraz Matki Boskiej z Dzieciątkiem, który jeszcze w XVIII w. został ozdobiony srebrną sukienką ${ }^{16}$. Wśród relikwii na pierwszym miejscu były relikwie Krzyża Świętego i kolec z Korony Cierniowej. Można przypuszczać, że forma nabożeństw odprawianych w Krasnem nie odbiegała od formy znanej z opisów ks. Jędrzeja Kotowicza (1728-1804) ${ }^{17}$.

Zgodnie z wolą fundatora kanonicy prowadzili szpital dla dwunastu osób niezdolnych do pracy na pańskim polu, uposażony przez Krasińskich. Z akt wizytacji wiemy, że ubodzy ze szpitala otrzymywali od Krasińskich deputaty $\mathrm{w}$ postaci wyżywienia i ubrania ${ }^{18}$. Ubogim ze szpitala wydawano: „quartualiter na każdego ubogiego cztery garce kaszy, tyleż grochu, trzy funty słoniny, kwartę soli, jarzyny albo rzepy z pola ile na Krasnym wydostarczyć mogło"19. Ubodzy ze szpitala, wyłącznie mężczyźni, wykonywali prace w kościele, zamian za dodatkową porcję jedzenia, bo: „,bardziej byli do posługi kościelnej używani i w piecach palili" ${ }^{20}$.

\footnotetext{
${ }^{16}$ I. G a li c k a, H. S y g i e ty ń s k a, dz. cyt., s. 25.

${ }^{17} \mathrm{~J}$. K i t o w i c z, Opis obyczajów za panowania Augusta III, Wrocław 1950.

18 ADP, Krasne, Akta wizytacji 1756-1775, [b. sygn.], nr 267.

${ }^{19} \mathrm{~K}$. Bła że w s ki, Szpitale diecezji płockiej $w$ XVIII wieku, „Notatki Płockie”, nr 2 (2002), s. 11.

20 Tamże.
} 
Kanonicy nie tylko prowadzili duszpasterstwo w parafii, ale nadal uczestniczyli w życiu opactwa czerwińskiego, dotyczy to szczególnie prepozytów. Ks. Franciszek Jagodkowicz, który decyzją biskupa płockiego, wraz z prepozyturą krasnieńską, objął funkcję dziekana przasnyskiego $^{21}$. Jako prepozyt kraśnieński ufundował w 1686 r. srebrną sukienkę dla obrazu Matki Bożej Czerwińskiej, znajdującego się w opactwie czerwińskim. Zdobi ona ten obraz do dziś i jest uważana za najcenniejsze $\mathrm{z}$ czerwińskich wotów ${ }^{22}$. Prawdopodobnie było to wotum wdzięczności za utworzenie prepozytury w Krasnem i objęcie probostwa w Krasnem przez kanoników regularnych, co sugeruje napis na sukni: „Roku Pańskiego 168627 grudnia - Najwyższemu i Wszechmogącemu Bogu, Najświętszej Dziewicy Maryi, największy ze wszystkich i najbardziej zasługujący na odrzucenie grzesznik, niegodny Kanonii Czerwińskiej, zakonnik - to nikłe i nędzne dzieło rąk, ofiarowując poświęca: Józef Jagodkiewicz (sic!), Kanonik Regularny Laterański, pierwszy prepozyt w Krasnem"23.

Prepozyt kraśnieński został wyznaczony w kwietniu 1687 r. przez kapitułę generalną kanoników czerwińskich, jako jeden z delegatów, do przeprowadzenia wizytacji kanonicznej w samym konwencie czerwińskim i wszystkich prepozyturach opactwa ${ }^{24}$. Wizytacja ta rozpoczęła się 9 maja 1687 r. w klasztorze czerwińskim, a następnie objęła wszystkie prepozytury łącznie z Krasnem i skończyła się na prepozyturze w Łomnie 30 września $1867 \mathrm{r}^{25}$

Kolejni prepozyci z Krasnego również czynnie uczestniczyli w życiu macierzystego opactwa. Ks. Józef Trzebiński pełniąc urząd prepozyta w Krasnem przewodniczył dwóm kapitułom w Czerwińsku, w roku 1713 i 1715, zastępując opata ks. Jana Kazimierza Bokuma ${ }^{26}$. Kilku prepozytów kraśnieńskich obejmowało następnie urząd opata. Pierwszym był ks. Antoni Wieszczycki, który bezpośrednio z prepozytu-

21 W. Gó r a ls ki, Reforma organizacji dekanalnej $w$ diecezji płockiej za bpa Andrzeja Chryzostoma Załuskiego w 1693 r. „Studia Płockie”, t. 12 (1984), s. 117.

${ }^{22}$ J. N o w i ń s k i SDB, 400 lat obecności cudownego obrazu Matki Bożej Pocieszenia (Matki Bożej Czerwińskiej) na Jasnej Górze w Czerwińsku, „Seminare”, nr 33 (2013), s. 329.

${ }^{23}$ Napis w thumaczeniu K. D ę b s k i e g o, cytat za: J. N o w i ń s k i, dz. cyt., s. 329.

${ }^{24}$ H. F o 1 w a r s k i, dz. cyt., s. 39.

25 Tamże, s. 39- 40.

26 Tamże, s. 45. 
ry w Krasnem przeszedł w 1757 r. do opactwa czerwińskiego ${ }^{27}$. Kolejnymi opatami czerwińskimi, którzy poprzednio sprawowali urząd prepozyta kraśnieńskiego byli: ks. Mateusz Kraszewski (opat od 1759 r.), ks. Jan Żdżarski, który jeszcze jako prepozyt w Krasnem był też koadiutorem opata, zaś samodzielnie urząd opata sprawował w latach 1768-1775. Żdżarski był związany z prepozyturą w Krasnem już jako subdiakon w 1742 r. Właśnie wtedy został ukarany przez kapitułę kanoników, za brak pokory, ośmiodniowym rekolekcjami połączonymi z samobiczowaniem dwa razy dziennie. Prepozyturę kraśnieńska objął w 1765 r. po zmarłym prepozycie ks. Stefanie Mikrowskim. Ks. Żdżarski będąc prepozytem w Krasnem był także delegatem kapituły czerwińskiej do przeprowadzenia wizytacji w konwencie czerwińskim. Samodzielne rządy nad opactwem objął właściwie w 1767 r., bowiem we wrześniu tego roku zmarł opat ks. Tadeusz Kraszewski. Jednak oficjalnie ks. Jan Żdżarski objął opactwo czerwińskie 16 maja 1768 r. $^{28}$ Wydaje się, że z powodzeniem łączył urzędy opata czerwińskiegiego i prepozyta kraśnieńskiego. Kolejnym opatem, który wcześniej pełnił funkcje prepozyta w Krasnem był ks. Antoni Prus-Wołowski. Prepozyturę w Krasnem otrzymał 29 listopada 1775 r., po roku przeszedł do Zuzel, a w 1795 r. został opatem czerwińskim. Ostatni opat czerwiński, ks. Stanisław Długołęcki był wikariuszem w prepozyturze kraśnieńskiej.

Podobnie rzecz wygląda z przeorami czerwińskimi. Prepozytami w Krasnem byli późniejsi przeorzy w Czerwińsku: ks. Jan Słonczewski (przeor od 1726 r.), ks. Mateusz Kraszewski (przeor od 1747 r. i opat od 1759 r ${ }^{29}$. Biskup płocki Michał Poniatowski jako czerwiński opat komendatoryjny od 1765 r., prosił Stolicę Apostolską o zgodę dla ks. Józefa Sosnkowskiego na zatrzymanie opactwa klaustralnego wraz z prepozyturą w Krasnem i prepozyturą w Warszawie ${ }^{30}$.

\footnotetext{
27 Tamże, s. 58-59.

${ }^{28}$ Tamże, s. 63- 65 i 81.

29 Tamże, s. 47 i 61.

${ }^{30}$ Michał Poniatowski chał przeprowadzić reformę opactwa w Czerwińsku, w którym w tym czasie nastąpiło rozluźnienie obyczajów. Funkcja opata komendatoryjnego nie dawała mu takiej możliwości, dopiero objęcie stolicy biskupiej w Płocku w 1773 r. pozwoliło mu na podjęcie działań mających poprawić poziom życia zakonnego w opactwie czerwińskim.
} 
Krasińscy zachowali prawo prezenty w kościele w Krasnem. Wiemy, że 11 marca 1751 r. Błażej Krasiński ${ }^{31}$ jako kolator kościoła w Krasnem osadził na tymże probostwie ks. Antoniego Wieszczyckiego, który z tego probostwa przeszedł w 1757 r. do opactwa czerwińskiego $^{32}$. Nie oznacza to, że kapituła musiała zaakceptować bezwzględnie wybór Krasińskich. Krasińscy mogli, ale nie musieli korzystać $\mathrm{z}$ prawa prezenty, ponadto musieli przedstawić co najmniej dwóch kandydatów na urząd prepozyta, spośród których kapituła wybierała prepozyta. Tak było np. w przypadku objęcia prepozytury przez ks. Jana Żdżarskiego, którego kontrkandydatem na ten urząd był ks. Atonii Smoleński. O tym, że wybór prepozyta nie był zwykłą formalnością świadczy fakt, że kapituła pierwsze głosowanie przeprowadziła 20 maja 1765 r., a dopiero 31 sierpnia tego roku Jan Żdżarski został wybrany prepozytem w Krasnem ${ }^{33}$.

\section{Kasat opactwa czerwińskiego i prepozytury w Krasnem}

Gdy w kwietniu 1819 r. klasztor kanoników regularnych w Czerwińsku uległ kasacie decyzją arcybiskupa warszawskiego Franciszka Skarbka Malczewskiego, a ,fundusze klasztorów i Beneficyow tak zwane simplicia na utrzymanie celniejszego stanu kościelnego zwłaszcza na uzupełnienie uposażenia stołu Biskupów Kapituł i Seminariów obrócone były"34, uposażenie prepozytury kraśnieńskiej po kasacie klasztoru czerwińskiego nie przeszło na własność biskupa, ale pozostało przy probostwie. Prepozytem kraśnieńskim był wówczas ks. Franciszek Sułkowski herbu Sulima, który urząd objął w 1796 r. Papież zastrzegł, że w przypadku wakatu na probostwie pierwszeństwo w obsadzie tegoż ma każdy kapłan, który do kasaty klasztoru był ka-

${ }^{31}$ Błażej Krasiński odnotowany w księdze zmarłych opactwa czerwńskiego: „Die 2da Maii. [Memoria] illustrissimi Damiani Blasii in Krasne Krasinski, Prasnensis, Neomestensis etc. capitanei, ecclesiae praepositurali Krasnensis munificentissimi fundatoris, qui [...] obiit in Dobromil anno 1751mo, sepultus vero in Krasne" - za K. R. Proko p, Staropolskie varia biograficzno-chronologiczne $z$ nowożytnych źródet proweniencji kościelnej (uzupetnienie do kompendiów bio-bibliograficznych i herbarzy), ,Biuletyn biblioteki Jagiellońskiej”, nr 66 (2016), s. 188.

${ }^{32} \mathrm{H}$. F o 1 w a r s k i, $d z$. cyt., 58-59.

33 Tamże, s. 58-59.

34 A. K ow a lc z y k, Biblioteka kanoników regularnych $w$ czerwińsku, „Notatki Płockie", nr 1 (2009), s. 5. 
nonikiem regularnym. Już po kasacie klasztoru czerwińskiego ostatni opat czerwiński, który pełnił tę funkcję zaledwie trzy lata, ks. Stanisław Długołęcki herbu Grzymała został proboszczem w Krasnem ${ }^{35}$. Ks. Długołecki objął parafię w Krasnem 20 listopada 1820 r., zastępując dotychczasowego prepozyta ks. Sułkowskiego. Zdaniem Henryka Folwarskiego Stanisław Długołecki pozostał tam proboszczem do 1829 r. i, że jest to także data śmierci ks. Długołęckiego ${ }^{36}$. Jednak Hipolit Gawarecki pisze o Stanisławie Długołęckim w 1830 r., jako o żyjącym proboszczu: „Teraźniejszym proboszczem w Krasnem jest JW. Stanisław Długołęcki, ostatni opat Kanoników regularnych"37. Oczywiście rok 1830 jest datą wydania drukiem pracy Gawareckiego, więc teoretycznie jest możliwe, że Długołecki zmarł w grudniu 1829 r., ale dalsze ustalenia Folwarskiego są co najmniej wątpliwe. Podaje on, że 15 grudnia 1829 r. parafię w Krasnem, decyzją biskupa płockiego, objął Egidiusz Godlewski ${ }^{38}$. Jednak wydaje się to mało prawdopodobne. Godlewski, który figuruje w aktach diecezji płockiej pod imieniem Idzi, ekskanonik regularny, ur. w 1793 r., święcenia przyjął w 1816 r. Po święceniach został wikariuszem w prepozyturze kanoników w Błoniu, a po kasacie opactwa czerwińskiego był wikariuszem w parafii w Krasnem od 1821 r., zaś od 1825 r. był wikariuszem w Ostrołęce i komendarzem parafii w Troszynie od 1827 r. W 1833 r. przejął probostwo w Czerwińsku, jako komendarz po zmarłym ks. Onufrym Barcikowskim, ostatnim przeorze klasztoru czerwińskiego ${ }^{39}$ i pozostał na tym probostwie do 1855 r. Objął parafię w Krasnem dopiero w 1855 r. ${ }^{40}$,

\footnotetext{
${ }^{35}$ H. G a w a r e c k i, Pamiętnik historyczny płocki, s. 105-106.

${ }^{36}$ H. F o 1 w a r s k i, $d z$. cyt., s. 79.

${ }^{37}$ H. G a w a r e c k i, Pamiętnik historyczny płocki, s. 105.

${ }^{38}$ H. F o 1 w a r s k i, $d z$. cyt., s. 79.

${ }^{39}$ H. Folwarski błędnie podaje, że po ks. Barcikowskim proboszczem czerwińskim został ks. Sebastian Kowalewski, kapłan diecezjalny. Zarówno Akta wizytacji jak i Catalogus Ecclesiarum et Utriusque Cleri tam Saecularis quam Regularis Dioecesis Plocensis (Katalog diecezji płockiej za lata 1816-1879) przeczą tym informacjom. Ks. Sebastian Kowalewski był proboszczem parafii w Baboszewie od 1802 r. do $1861 \mathrm{r}$. i pełnił funkcje dziekana płońskiego - Archiwum Diecezjalne w Płocku. Akta dotyczace stanu diecezji płockiej, sygn. B-2, k. 136-150.

${ }^{40}$ Trudno ustalić skąd H. Folwarski czerpał informacje dotyczące Idziego Godlewskiego i Sebastiana Kowalewskiego. Podaje w przypisach, że są to dokumenty z Archiwum Kurii Płockiej. Możliwe, że chodzi o Archiwum Diecezjalne w Płocku. Wówczas tam, gdzie Folwarski podaje jako źródło „Acta Episcopalia” (nie precyzując o jakie konkretnie chodzi), można założyć, że zapewne chodzi o Acta Episcopalia
} 
a nie w 1829 r., jak chce Folwarski. Pozostaje problem kto był proboszczem w Krasnem po śmieci Długołęckiego, a przed objęciem probostwa przez Godlewskiego, który był ostatnim ekskanonikiem regularnym na probostwie w Krasnem i sprawował ten urząd do swojej śmierci w 1879 r. ${ }^{41}$ Wysoce prawdopodobne, że Idzi Godlewski był w ogóle ostatnim kanonikiem $\mathrm{z}$ opactwa czerwińskiego. Tym samym zakończył ponad stuletni okres bytności kanoników regularnych laterańskich w Krasnem.

\section{Kościól parafialny w Krasnem}

Kościół w Krasnem na Mazowszu jest najstarszym z kościołów fundacji Krasińskich. Początki kościoła w Krasnem sięgają 1380 r., a jego fundatorem był protoplasta rodu Krasińskich Sławomir de Krasne herbu Ślepowron ${ }^{42}$. Adam Boniecki o Sławomirze de Krasne pisze: „Najdawniejszym dziedzicem Krasnego, w aktach wspomnianym, jest Sławomir, któremu sąd ziemski ciechanowski oznaczył w 1372 r. granice Krasnego, od własności sąsiedniej Niedomysła. Tenże sam Sławomir z Krasnego, wspólnie z Krystynem z Drozdzina, nabył w 1377 r. Czernice, w ziemi ciechanowskiej, od Pełki z Czernic. Sławomira synów dwóch: Rosław i Jasiek. Śmichna, pozostała wdowa po Jaśku (...)"43.

Pierwsza wzmianka o parafii w Krasnem pochodzi z Metryki Koronnej i widnieje pod datą 1443 r., kościół był wówczas pod wezwaniem św. Jana Chrzciciela ${ }^{44}$. Była to świątynia drewniana i w takiej formie przetrwała do roku 1570. Chociaż prawdopodobne jest, że w 1570 r. nie był to ten sam kościół, ale kolejny, również drewniany,

(1448-1849) z Archiwum Diecezjalnego w Płocku. Jednak nie znalazłem potwierdzenia informacji podanych przez Folwarskiego w Acta Episkopalia w ADP. Inni historycy opierający swoje prace na materiałach z ADP podają, inaczej niż H. Folwarski, że ks. Idzi Godlewski był proboszczem w Czerwińsku w lach 1833-1855, a proboszczem w Krasnem został w 1855 - por. M. M. G r z y b o w s k i, Idzi Godlewski (1793-1879), [w:] Duchowieństwo diecezji płockiej, t. 3, Płock 2012, s. 90-91; Z. L a t o SDB, Troska salezjanów o ośrodki kultu maryjnego w Polsce w latach 1989-1988, „Seminare. Poszukiwania Naukowe", nr 14 (1998), s. 152.

${ }^{41}$ F. Ł y d y ń s k i, $d z$. cyt., s. 26.

42 T. Ż e brow s k i, Kościół (XIV-początek XVI w.), [w:] Dzieje Mazowsza, t. 1, Pułtusk 2006, s. 472.

${ }^{43}$ A. B o n i e c k i, Herbarz polski, t. 12, cz. 1, Warszawa 1908, s. 184.

44 A. B orki e w i c z-C e lińs k a, Osadnictwo ziemi ciechanowskiej, 1970, s. 67; MK 3, 283. 
wystawiony w tym miejscu przez potomków Sławomira. Możliwe, że ostatni drewniany kościół został wzniesiony w Krasnem przez Mikołaja Krasińskiego w 1482 r. Bartosz Paprocki pisze, że Mikołaj: „fundował ecclesiae parochiali in Crasne, coram Petro de Chotkovo episcipo plocen, roku 1482"45. Kasper Niesiecki powtarza tę informację za Paprockim ${ }^{46}$. Wiemy, że w 1570 r. kościół został przebudowany przez Franciszka Krasińskiego, biskupa krakowskiego i podkanclerzego koronnego.

Hipolit Gawarecki podaje, że w 1570 r. Franciszek Krasiński, ufundował nowy, murowany kościół ${ }^{47}$. W 1826 r. podczas remontu kościoła odnaleziono kamień, który potwierdza fundację biskupa Franciszka Krasińskiego, jak i rok 1570 jako jej datę ${ }^{48}$. Informacja o fundacji kościoła przez biskupa krakowskiego jest nieścisła. Pierwszy kościół był ufundowany przez Sławomira de Krasne jeszcze w XIV w., możliwe, że w 1482 r. wzniesiono w tym miejscu kolejny kościół. Franciszek Krasiński nie wystawił murowanego kościoła, ale ufundował murowaną nawę $\mathrm{z}$ wieżą ustawioną osiowo, zaś prezbiterium pozostało nadal drewniane. Bracia biskupa krakowskiego: Wojciech - kasztelan sierpecki i Andrzej - sędzia ciechanowski, ufundowali dwie kaplice boczne, murowane, odnotowane w 1609 r. ${ }^{49}$. Kaplice były pod wezwaniem św. św. Andrzeja i Katarzyny i św. Wawrzyńca. W 1575 r. miała miejsce reerekcja parafii i konsekracja kościoła przez biskupa płockiego Piotra Myszkowskiego ${ }^{50}$. Kontrowersje budzi rok ukończenia budowy kościoła, historycy podają tutaj dwie możliwe daty: rok 1570 i rok reerekcji parafii, czyli 1575. Wspominany już kamień odnaleziony podczas remontu kościoła w 1826 r., wskazuje na rok 1570 . W tym wypadku chodzi nie tylko o datę podaną na tymże kamieniu, ale i o tytulaturę Franciszka

${ }^{45}$ B. P a procki, Herby rycerstwa polskiego, zebrane $i$ wydane $r$. p. 1584, wyd. K. J. T u row s k i, Kraków 1858, s. 406.

${ }^{46}$ K. N i e s i e cki, Herbarz Polski, t. 5, Lipsk 1840, s. 364. F. Łydyński pisząc o kolejnej budowie kościoła w 1482 r. wydaje się mieć wątpliwości: „Kolejna (?) budowla (...) widnieje pod datą 1482". Łydyński nie podaje źródła tej informacji, ale możemy domniemywać, że jest nią Niesiecki - por. F. Ł y d y ń s k i, op. cit., s. 25.

${ }^{47} \mathrm{H}$. G a w a r e c k i, Pamiętnik historyczny płocki, s. 100.

48 „Korespondent Płocki”, 5 luty 1880, s. 3.

${ }^{49}$ I. G a li c k a, H. S y g i e ty ń s ka, $d z$. cyt., s. 21-22.

${ }^{50}$ ADP, Krasne. Akta wizytacji 1844-1846, [b. syn.]. Łydyński podaje rok 1578 jako datę konsekracji kościoła, ale kolejny raz nie podaje źródła informacji - F. Ł y d y ń s k i, dz. cyt., s. 25. 
Krasińskiego: Franciscus Krasiński Praep. Ploc. ac Vice Cancel. Reg. Pol. hanc ecclesiam ex fundamentis extruxit A.D. MDLXX. Jest on tytułowany jako prepozyt płocki i podkanclerzy koronny, brak zaś w tym miejscu tytułu biskupa krakowskiego. Franciszek posiadał prepozyturę płocką w latach 1568-1574, zaś godność podkanclerzego pełnił do 1572 r. W tym samym roku został również biskupem krakowskim ${ }^{51}$. Zatem napis musi pochodzić sprzed roku 1572, co każe nam przypuszczać, że data podana na kamieniu jest wiarygodna. Nieporozumienie w sprawie daty ukończenia budowy kościoła wynika z treści dokumentu erekcyjnego kościoła, w którym zapisano: Ego Franciscus Krasiński de Krasne Dei Gratia Episcopus Cracoviensis. Jednak dokument ten został spisany w drugiej połowie XIX w. przez proboszcza współczesnego Hipolitowi Gawareckiemu, co ten ostatni potwierdził: „dokument na pergaminie pisany przez teraźniejszego proboszcza",52, chodzi oczywiście o ks. Stanisława Długołeckiego.

Po przebudowie była kościół był świątynią jednonawową z dwiema kaplicami i drewnianym prezbiterium ${ }^{53}$. W formie nadanej przez biskupa krakowskiego i jego braci przetrwał do połowy XVII w. W połowie XVII w. Jan Kazimierz Krasiński, wojewoda płocki, wraz ze staraniem o erekcję prepozytury kanoników czerwińskich rozpoczął przebudowę kościoła od strony wschodniej i powiększył grobowiec rodowy, który znajduje się pod kościołem.

Prace budowlane były kontynuowane przez jego syna Jana Dobrogosta Krasińskiego starostę przasnyskiego, warszawskiego, opinogórskiego, (od 1668 r. również, tak jak ojciec) wojewodę płockiego ${ }^{54}$. Był on także fundatorem dwóch kościołów w Węgrowie: kościoła reformatów i kościoła farnego, przy którym osadził bartolomitów.

Księgi metrykalne parafii $\mathrm{w}$ Krasnem potwierdzają prace murarzy przy kościele parafialnym w latach 1678-1681, z nazwiska są wymie-

\footnotetext{
51 Krasiński był prekonizowany 2 lipca 1572 r. pierwszy akt jako biskup nominat krakowski wydał już 10 lipca 1572 r., zaś konsekrowany został 6 stycznia 1573 r. Zapisy Krasińskiego jako podkanclerzego koronnego w księgach podkanclerskich kończą się 23 maja $1572 \mathrm{r}$.

${ }^{52}$ H. G a w a r e c k i, $d z$. cyt., s. 101, p. 3.

53 Archiwum Diecezjalne w Płocku (dalej: ADP), Akta wizytacji archidiakonatu ptockiego z 1609 r. sygn. 5, k. 199-202.

54 A. Pr z y b o ś, Krasiński Jan Dobrogost, [w:] Polski Słownik Biograficzny, t. 15, Wrocław-Warszawa-Kraków 1970, s. 181.
} 
nieni murarze: Jan Mościcki, Jan Szeszalowicz i Stanisław Rzyżynski ${ }^{55}$. Zakres prac prowadzonych przez Jana Dobrogosta Krasińskiego jest nieznany, ale wiadomo, że odpowiada on za budowę nowego prezbiterium na przesklepionych podziemiach wystawionych jeszcze przez Jana Kazimierza Krasińskiego. Świadczy o tym kolejna konsekracja kościoła w 1684 r. już pod wezwaniem Podwyższenia Krzyża Świętego (dotąd był pod wezwaniem Jana Chrzciciela) ${ }^{56}$. Nowe wezwanie należy zapewne wiązać $\mathrm{z}$ faktem, iż w kościele znajdowały się relikwie Krzyża Świętego, po raz pierwszy wzmiankowane w 1599 r. ${ }^{57}$. Konsekracja była konsekwencją rozebrania starego i ukończenia budowy nowego, już murowanego prezbiterium.

Za całkowicie błędny należy uznać pogląd Ferdynanda Łydyńskiego, który pisze: „Ponieważ w 1684 r. kościół został rekonsekrowany należy podejrzewać, że jest to jednocześnie przybliżona data rozbiórki drewnianego prezbiterium i rozpoczęcia murowania nowego"58. Konsekracji kościoła dokonuje się nie przed rozbiórką, czy przed rozpoczęciem budowy prezbiterium, ale po ukończeniu jego budowy. Sama konsekracja polega m.in. na namaszczeniu ścian kościoła i ołtarza. $\mathrm{W}$ związku z tym, jeżeli ściany poświęcone i namaszczone, zostaną rozebrane, a na ich miejsce wystawione nowe, to kościół może być ponownie konsekrowany, czyli namaszczano nowe ściany. To właśnie na ścianach umieszczono w miejscu, w którym mury były namaszczone olejem, signa in parietibus. Najczęściej były to zacheuszki, które uważane były za dowód konsekracji kościoła. Rozebranie ścian oznaczało oczywiście usunięcie signa in parietibus, ponowne ich umieszczenie wymagało namaszczenia murów, a więc konsekracji. Konsekracja w 1684 r. nie oznaczała, że budowa została ukończona właśnie w tym roku, mogła zostać ukończona wcześniej, zapewne około $1681 \mathrm{r}$. lub 1682 r., ale z całą pewnością nie później niż w 1684 r. Natomiast za wręcz kuriozalny należy uznać pogląd, że konsekracja w $1684 \mathrm{r}$. miała związek z przejęciem w 1681 r. kościoła przez kanoników regu-

${ }^{55}$ ADP, Ksiegi metrykalne w Krasnem. Księga urodzeń 1657-1681, sygn. 529. s. 100-105; ADP, Księgi metrykalne w Krasnem. Księga urodzeń 1681-1710, sygn. 530. s. 86. ${ }^{56}$ Ibidem.

${ }^{57}$ ADP, Akta wizytacji archidiakonatu plockiego z 1598-1599 r., sygn. 5, k. 200.

${ }^{58}$ F. Ł y d y ń s ki, dz. cyt., s. 25. 
larnych, jak to podaje Łukasz Piotr Młynarski ${ }^{59}$. Przejęcie kościoła przez zakonników, w tym wypadku kanoników regularnych, nie tylko absolutnie nie pociąga za sobą konieczności ponownej konsekracji kościoła, ale nawet nie może stanowić jej powodu. Młynarski błędnie też zinterpretował informację z Akt wizytacji 1844-1846 $6^{60}$ i Ksiag metrykalnych $w$ Krasnem $^{61}$, że budowę zaczął i skończył Jan Kazimierz, a prace prowadzone w 1678 i 1681 r. stanowiły odrębną budowę. Tymczasem, w świetle tych zapisów lat 1678-1681 r., wydaje się słuszna konstatacja, że Jan Kazimierz Krasiński rozpoczął budowę prezbiterium i podziemi w 1678 r., a po jego śmierci kontynuował ją jego syn, Jan Dobrogost Krasiński i zakończył ją w 1681 r. Zaś konsekracja była związana z zakończeniem budowy prezbiterium i z całą pewnością nie ma nic wspólnego z przejęciem kościoła przez kanoników regularnych w $1681 \mathrm{r}$.

Warto podkreślić, że pisząc o konsekracji biorę pod uwagę ówcześnie obowiązujące przepisy liturgiczne i z zakresu prawa kanonicznego, a nie współcześnie. Nowe prawo liturgiczne nie używa terminu „konsekracja” stosując w jego miejsce słowo „dedykacja”,62. W wieku XVIII przez dedykację rozumiano zarówno poświęcenie jak i konsekrację. I tutaj ponownie należy wyjaśnić, że poświęcenie wówczas było obrzędem mniej uroczystym niż błogosławieństwo (benedykcja), która była synonimem konsekracji ${ }^{63}$. Dzisiaj jest odwrotnie.

Z akt wizytacji parafii krasnieńskiej z 1756 r. wiemy, że miała miejsce także trzecia konsekracja kościoła: „Błażey na Krasnem Krasiński miał wolę (...) dopiero o konsekrację się postarać całkowitego kościoła $^{64}$, . Praxis episcopalis autorstwa Pawła Piaseckiego stwierdzało, że kościół może być uznany za konsekrowany, gdy potwierdzi to nawet jeden świadek, wzmianka w kronice, lub napis na ścianie,

${ }^{59}$ Ł. P. Mł y n a r s k i, Kościól i mauzoleum Krasińskich $w$ Krasnem $w$ okresie nowożytnym. Przyczynek do dziejów obiektu, [w:] Franciszka z Krasińskich Wettyn, red. D. K a l i n a, R. K u b i c k i, M. W a r d z y ń s k i, Kielce-Lisów 2012, s. 56.

${ }^{60}$ ADP, Krasne. Akta wizytacji 1844-1846, [b. sygn.], s. 1.

${ }^{61}$ ADP, Księgi metrykalne w Krasnem. Księga urodzeń 1657-1681, sygn. 529, s. 100-105; ADP, Księgi metrykalne w Krasnem. Księga urodzeń 1681-1710, sygn. 530. s. 86.

${ }^{62}$ Ordo dedicationis ecclesiae et altaris, Typis Polyglottis Vaticanis 1977.

63 W Encyklopedii Kościelnej czytamy: „Niektóre z tych benedykcji biskup może zlecić kapłanowi, innych zaś nie. Nie może zlecić tych, w których zachodzi namaszczenie, jak konsekracja kościoła, ołtarza, kielicha (...)" - Encyklopedia Kościelna, t. 2, Warszawa 1873, s. 405.

${ }^{64}$ ADP, Krasne, Akta wizytacji 1756-1775, [b. sygn.], s. 75. 
a nawet grzebanie zmarłych wewnątrz budynku ${ }^{65}$. W przypadku kościoła w Krasnem zachodziły wszystkie te przesłanki. Jednak został on konsekrowany w 1756 r., już po raz trzeci. Wydaje się, że można to wyjaśnić analizując akta wizytacji kościoła w Krasnem z lat 17561775. Z akt tych wynika, że Błażej Krasiński, nie przebudował kościoła, ale wystawił nowy. Prace rozpoczęły się w 1739 r. od uroczystości wmurowania kamienia węgielnego, w których uczestniczył Paweł Szczuka, proboszcz pułtuski i audytor biskupa płockiego. Dalej jest wprost mowa, że Błażej wystawił nowy kościół, którego nie zdążył urządzić przed śmiercią, a nie przebudował stary ${ }^{66}$. Istotnie zakres prac prowadzonych przez Błażeja był duży: obejmował rozebranie nawy głównej i kaplic bocznych, w to miejsce wystawiono od fundamentów trójnawowy korpus, wieżę kościoła rozebrano do połowy i wzniesiono na nowo oraz wybudowano nową zakrystię ze skarbcem. Ze starego kościoła pozostała tylko elewacja z połową wieży i prezbiterium wystawione przez Jana Dobrogosta. Jak widać prace te mogą zostać uznane za budowę kościoła, a nie wyłącznie przebudowę. Ponadto rozbierając ściany nawy ponownie usunięto signa in parietibus. To wyjaśnia, dlaczego mamy do czynienia z trzecią konsekracją kościoła w Krasnem.

Musimy zauważyć, że wszystkie konsekracje (1575, 1684 i 1756) miały miejsce zawsze po wystawieniu de facto nowego kościoła, a z całą pewnością zasadniczej części kościoła, jak prezbiterium czy nawy. W roku 1756 z kościoła ufundowanego przez biskupia Franciszka Krasińskiego i konsekrowanego w 1575 r. pozrastał tylko mur elewacji frontowej (sama elewacja była przebudowana w XVII w.) i połowa wieży. Nawet współczesne przepisy liturgiczne mówią, że kościół może być konsekrowany (współcześnie jest to termin „poświęcony”), gdy pojawi się zasadnicza zmiana w jego konstrukcji na przykład, gdy budynek został całkowicie przebudowany ${ }^{67}$. W przypadku kościoła w Krasnem wszystkie trzy konsekracje miały miejsce po przebudowie kościoła, która zasadniczo zmieniała konstrukcję budynku. Różnica w staropolskim rozumieniu przepisów o konsekracji po przebudowie kościoła, od współczesnych polega na tym, że w okresie staropolskim wprost stwierdzano, że konsekracja jest do-

\footnotetext{
${ }^{65}$ P. P i a s e c k i, Praxis episcopalis, Cracoviae 1627, s. 98-99.

${ }^{66}$ ADP, Krasne, Akta wizytacji 1756-1775, [b. sygn.], s. 75.

${ }^{67}$ Obrzędy poświęcenia kościoła i ottarza, wyd. wzorcowe, Katowice 2001, rozdz. III nr 1.
} 
puszczalna, gdy zostaną rozebrane namaszczone ściany. W przypadku kościoła w Krasnem zachodziła właśnie taka sytuacja. W związku z tym należy sprostować, że nie mamy do czynienia $\mathrm{z}$ rekonsekracją kościoła, czy ponowną konsekracją kościoła, jak to bywa podawane ${ }^{68}$, ale po prostu $\mathrm{z}$ konsekracją. Po za porządkiem prawnym należy uwzględnić też sprawy czysto ambicjonalne, prestiżowe. Prawo, także prawo kanoniczne, naginano nie tylko w okresie staropolskim, dostosowując je do oczekiwań elity. Konsekracja kościoła w sposób oczywisty podnosiła prestiż kościoła i świadczyła o randze fundatora. Nie może dziwić, że kościół fundowany przez biskupa krakowskiego Franciszka Krasińskiego był konsekrowany, tutaj też sprawa prawna jest oczywista. Podobnie rzecz ma się z konsekracją z 1684 r. pod względem prawnym wystawienie nowego prezbiterium również usprawiedliwia konsekracje, ale nie bez znaczenia jest osoba fundatora i jego pozycja. Jan Kazimierz Krasiński, podskarbi wielki koronny, wojewoda płocki od 1650 r., podkomorzy ciechanowski, starosta ciechanowski, opinogórski, był żonaty z Urszulą Grzybowską, kasztelanką lubelską, z którego to związku narodził się Jan Dobrogost. Po śmierci Urszuli (1647 r.) Jan Kazimierz ożenił się powtórnie 9 stycznia 1650 r. z Amatą Andreą Andrault, hrabianką de Langeron, córką wielkorządcy newerskiego i damą dworu oraz powiernicą królowej Ludwiki Marii $^{69}$. Jan Dobrogost Krasiński, referendarz wielki koronny, wojewoda płocki, starosta warszawski i opinogórski, był marszałkiem sejmików generalnych mazowieckich $(1664,1673,1678)$, dowodził chorągwią husarską w czasie bitwy wiedeńskiej, był bliskim przyjaciel króla Jana III Sobieskiego.

W przypadku konsekracji z 1684 r., zgodnie z ówczesną interpretacją przepisów prawa koranicznego znaną nam przywoływanego już Praxis episcopalis ${ }^{70}$, konsekracja nie była konieczna, ale była jak najbardziej dopuszczalna. W tym wypadku zdecydowała nie konieczność, ale prestiż fundatorów. Wszystkie kościoły fundowane przez Jana Dobrogosta były konsekrowane tuż po zakończeniu budowy, co wcale nie było częstą praktyką. W przypadku fary węgrowskiej fundowanej przez Jana Dobrogosta pod względem prawnym konsekracja

\footnotetext{
${ }^{68}$ Ł. P. M $\nmid$ y n a r s ki, $d z$. cyt., s. 56; F. Ł y d y ń s k i, dz. cyt., s. 25.

${ }^{69}$ A. B o n i e c k i, $d z$. cyt., s. 197.

${ }^{70}$ P. P i a s e c k i, $d z$. cyt., s. $98-99$.
} 
również nie była konieczna, ze starego kościoła zachowano mury zarówno prezbiterium jak nawy, co potwierdza zachowany kontrakt zawarty 12 sierpnia 1703 r. pomiędzy Janem Dobrogostem Krasińskim a Carlo Ceronim, którego świadkiem był Józef Belloti (Joseph Bellolty ${ }^{71}$. W tym wypadku konsekracja, która miała miejsce w 1711 r. była dopuszczalna, ale wcale nie była konieczna. Podobnie rzecz ma się z konsekracją kościoła krasnieńskiego z 1756 r. W tym czasie Krasne było w posiadaniu Jana Józefa Krasińskiego, ojca Adama Stanisława Krasińskiego i Michała Hironima Krasińskiego. Adam Stanisław Krasiński był również znaczącą postacią, od 1752 r. był sekretarzem wielkim koronnym, a od 1751 r. jako deputat kapituły płockiej zasiadał w Trybunale Koronnym. W 1753 r. został kanonikiem gnieźnieńskim, o jego znaczącej pozycji świadczy fakt, że w 1759 r. został biskupem kamienieckim. Jego krewnym i bliskim przyjacielem, ale też współpracownikiem, był Kajetan Sołtyk, wówczas biskup kijowski, a później biskup krakowski, jego kuzyn Jan Kanty Krasiński był biskupem sufraganem chełmskim ${ }^{72}$. Choćby $\mathrm{z}$ tych względów żaden biskup nie odmówiłby prośbie Krasińskich o konsekrację kościoła.

W dokumentach archiwalnych nie zachowała się informacja o architektach zatrudnionych przez Krasińskich do kolejnych prac przy kościele w Krasnem. Znamy nazwiska architektów, których Jan Dobrogost Krasiński zatrudniał przy swoich fundacjach, byli to: Tylman z Gameren, Carlo Ceroni, Izydor Affaita (młodszy), Józef Szymon Bellotti, a jego marszałkiem dworu został także architekt, Jan Reisner. Jednak wydaje się, że architekta przebudowy kościoła zakończonej w 1684 r. należy szukać nie w kręgu architektów Jana Dobrogosta, ale w kręgu architektów jego ojca Jana Kazimierza Krasińskiego. Chociaż budowę prezbiterium prowadzono za czasów Jana Dobrogosta Krasińskiego, co potwierdzają przywoływane już Ksieggi metrykalne w Krasnem z ADP, jak i data rekonsekracji kościoła, to najprawdopodobniej był on tylko kontynuatorem prac rozpoczętych przez Jana Kazimierza Krasińskiego. Wydaje się to potwierdzać fakt, że to właśnie Jan Kazimierz jest wymieniany jako fundator prac przy kościele w Krasnem w Aktach Wizy-

71 Archiwum Diecezjalne w Drohiczynie, ZAPW, Kontrakt pomiędzy Janem Bonawenturą Krasińskim a Carlem Ceronim, sygn. III/Q/1/B, k. 1, s. 1.

72 W. J. Gó r c z y k, Biskup kamieniecki Adam Stanisław Krasiński (1714-1800). Szkic do studium biograficznego, „Bieżuńskie Zeszyty Historyczne”, nr 31 (2017), s. 62-98. 
tacji parafii $w$ Krasnem 1844-1846 $6^{73}$. Tutaj też zapewne należy upatrywać źródeł wspomnianego błędu popełnionego przez Młynarskiego, który analizując akta w ADP zinterpretował te zapisy jako informację, że parce zaczął i skończył Jan Kazimierz, a konsekracja była związana z przejęciem kościoła przez kanoników regularnych.

Przebudowa kościoła w Krasnem rozpoczęta przez Jana Kazimierza Krasińskiego i kontynuowana przez Jana Dobrogosta, niewątpliwie związana $\mathrm{z}$ fundacją prepozytury czerwińskiej, miała na celu także uczynienie $\mathrm{z}$ tego miejsca, a właściwie ugruntowanie tego miejsca, jako mauzoleum rodowego Krasińskich. Pierwsze pochówki Krasińskich w kościele krasnieńskim miały miejsce jeszcze w XVI w. Sam fundator murowanego kościoła, biskup krakowski Franciszek Krasiński, spoczął w kolegiacie w Bodzentynie, gdzie znajduje się jego nieatrybuowany pomnik nagrobny, pochodzący z warsztatu Hieronima Canavesiego ${ }^{74}$. W kościele w Krasnem Andrzej Krasiński, brat Franciszka, ufundował kaplicę św. Andrzeja, została ona erygowana w 1579 r., a sklepiona 1609 r. $^{75}$. Prawdopodobnie była to kaplica grobowa Krasińskich i w tej kaplicy znajdowały się dwa sepulkralia. Pierwszym było epitafium Jana i Katarzyny Krasińskich, rodziców Andrzeja i Franciszka, z końca XVI w. Drugim był piętrowy pomnik nagrobny Andrzeja i Katarzyny Krasińskich, który bywa przypisywany Hieronimowi Canavesciemu,

\footnotetext{
${ }^{73}$ ADP, Krasne. Akta wizytacji 1844-1846, [b. sygn.], s. 1.

74 Grób Franciszka Krasińskiego w Bodzentynie został zamurowany w XVIII w., wtedy też zamurowano XV w. polichromię w prezbiterium. Dopiero podczas restauracji kościoła w XIX w. odsłonięto na nowo nagrobek Franciszka Krasińskiego, Franciszek Maksymilian Sobieszczański pisząc o swoim pobycie w Bodzentynie w 1851 r., stwierdza: „przy obecnej restaurayi odkryto grób tego biskupa”. Poprawną wersję tekstu na epitafium odczytał w 1904 r. A. J a now s k i: Francisco Crassino (?) de Crasne gente Slepovron Episcopo Cracoviensi et ante regni procancellario, viro mansueto, prudenti et moderato qui cum (...) bis apud Paulum IIII Pont. Maxim. cpiscoporum totiusque Cleri Polonici, et apud Maxim. II Rom. Imper. etiam bis Sigis. Augusti R. Poloniae nomine legationis munus cum laude ob (...) qui factus in negotiis cancellario executionis legum et unionis Magni Ducatus Lithuaniae (...) cum Regno duobusque scquentibus interregnis licet am valetudinarius egregiam operam Reip. navavit (...) martii a. d. MDLXXVII aetatis suae (...) - W. J. Gó r c z y k, Pomniki nagrobne biskupa krakowskiego Franciszka Krasińskiego $i$ wojewody płockiego Stanisława Krasińskiego, „Muzealne Rozmaitości”, nr 1 (2018), s. 10-11

75 D. P r z y $ł$ u b s k a, Nagrobek Andrzeja i Katarzyny Krasińskich w kościele w Krasnem, ,Mazowsze”, nr 7 (1/96), s. 37.
} 
zaś Dorota Przyłubska przypuszcza, że autorem tegoż był Santi Gucci ${ }^{76}$. Również Jan Dobrogost początkowo widział w tym kościele miejsce sepulkralne rodu. Tutaj pochował, w podziemiach kościoła, swojego ojca, w sarkofagu, który ten wzniósł jeszcze za swojego życia. Spoczęły tutaj także obie żony Jana Dobrogosta, Teresa z Chodkiewiczów i Jadwiga Teresa $\mathrm{z}$ Jabłonowskich, którym ufundował wspólny nagrobek wykonany przez Andreasa Mackensena Młodszego. Mackensenowi Krasiński zlecił także wykonanie swojego pomnika nagrobnego w kościele reformatów w Węgrowie ${ }^{77}$. Nagrobek żon Jana Dobrogosta znajdował się w środku prezbiterium kościoła kraśnieńskiego. W kościele tym spoczął także biskup kamieniecki Adam Stanisław Krasiński (†1800), który po likwidacji swojej diecezji przez Katarzynę II w 1795 r., stale rezydował w Krasnem ${ }^{78}$. W Krasnem pochowana jest również żona hrabiego Zygmunta Krasińskiego, wieszcza narodowego, hrabina Eliza z Branickich Krasińska (†1876).

W latach trzydziestych i czterdziestych XVIII w. na zlecenie Błażeja Jana Krasińskiego, starosty opinogórskiego i przasnyskiego, kościół w Krasnem został ponownie przebudowany ${ }^{79}$. Przebudowa ta prowadzona od 1739 r. do ok. 1749 r. w zasadniczy sposób zmieniła wygląd kościoła. Dotąd jednonawowa świątynia $z$ dwiema kaplicami: św. Wawrzyńca z ołtarzem św. Anny i kaplica św. Andrzeja, przybrała wygląd bazyliki trójnawowej ${ }^{80}$. Spowodowało to konieczność przeniesienia nagrobków Krasińskich z kaplicy św. Andrzeja w inne miejsca w kościele. W ten sposób pomnik Andrzeja i Katarzyny Krasińskich znajduje się obecnie w ścianie nawy północnej kościoła, a epitafium Jana i Katarzyny Krasińskich w nawie południowej. Podobnie jak w przypadku przebudowy zapoczątkowanej przez Jana Kazimierza Krasińskiego, mamy problemy z jednoznacznym wskazaniem architekta. Młynarski zakwestionował autorstwo projektu Antonio Solariego, wskazując, że atrybucja ta

\footnotetext{
76 Tamże, s. 38.

${ }^{77}$ W. J. G ó r c z y k, Reformaci w Wegrowie. Architektura kościoła i miejsce fundacji węgrowskiej na tle działalności fundacyjnej Krasińskich, s. 312.

${ }_{78}$ T e nże, Biskup kamieniecki Adam Stanisław Krasiński (1714-1800). Szkic do studium biograficznego, s. 91 .

${ }^{79}$ I. G a li c k a, H. S y g i e ty ń s k a, dz. cyt., s. 22.

${ }^{80}$ F. Ł y d y ń s k i, dz. cyt., s. 25; H. S a m s o n o w i c z, Freski Sebastiana Ecksteina w kościele $w$ Krasnem, „Mazowsze”, 7/(I/96), s. 31; I. G a l i c k a, H. S y g i e t y ń s k a, dz. cyt., s. 22.
} 
„Najpewniej wynika (...) z pomyłki przy analizie zachowanego fragmentu ekspensy na wzniesienie domu tutejszych zakonników (...)"81. Jednak materiały z ADP, które analizuje Młynarski mówią o budowie plebani, a nie kościoła ${ }^{82}$. Atrybucja jest autorstwa I. Galickiej i H. Sygietńskiej, ale nie wynika ona wcale z analizy wspomnianej ekspensy, tym bardziej błędnej analizy, jak to sugeruje Młynarski, ale $\mathrm{z}$ analizy stylistyczno-porównawczej architektury kościoła ${ }^{83}$.

Sytuację $\mathrm{z}$ atrybucją korpusu kościoła dodatkowo komplikuje fakt, że w Krasnem w latach 1739-1741 jest poświadczona obecność architekta Marcina Wiśniewskiego ${ }^{84}$. Jednak w tym wypadku wydaje się słuszne przypuszczenie Młynarskiego, że Wisniewski tylko kierował pracami $^{85}$, zaś autorem projektu był inny architekt, być może właśnie Antonio Solari, jak sądzą Galicka i Sygietyńska.

Wiemy zaś z całą pewnością, że Sebastian Eckstein w 1747 r. na polecenie Błażeja Krasińskiego wykonał polichromię i namalował również sceny drogi krzyżowej w kościele kraśnieńskim ${ }^{86} \mathrm{w}$ technice fresku mokrego ${ }^{87}$. Całość stanowi cykl 19 kompozycji ściennych. Freski były sygnowane przez Ecksteina: „Sebastian Eckstein Adornavit Picturis Anno 1747"88. Zatem rok 1747 należy traktować jako możliwie najpóźniejszą datę zakończenia budowy przynajmniej naw bocznych, zaś budowa zakrystii i skarbca nad zakrystią mogła zostać ukończona w 1749 r. Pochodzący z Moraw Sebastian Eckstein pojawił

${ }^{81}$ Ł. P. M ł y n a r s k i, dz. cyt., s. 57.

82 ADP, Archiwum Parafialne w Krasnem. Odpis 1825, k. XXXV.

${ }^{83}$ W. B o b e r s k i, Solari (Solary) Antonio(1700-1763), PSB, t. 40, z. 2, 2000, s. 247.

${ }^{84}$ Ł. P. M ł y n a r s k i, dz. cyt., s. 57.

85 Tamże.

${ }^{86}$ W latach 1877-1883 podczas restauracji kościoła Antoni Strzałecki przemalował freski Ecksteina i zamalował sygnaturę. Dopiero w latach pięćdziesiątych XX wieku zdjęto przemalunki i odsłonięto sygnaturę Ecksteina - H. S a m s o n o w i c z, dz. cyt., s. 31 .

${ }^{87} \mathrm{~W}$ roku 2017 zakończył się szósty sezon projektu restauratorsko-konserwatorskiego oraz badawczego fresków Sebastiana Ecksteina w kościele w Krasnem prowadzonego przez Wydział Konserwacji i Restauracji Dzieł Sztuki ASP w Warszawie.

${ }^{88}$ Sygnatura jest widoczna na Scenie ,Złożenie do grobu”, prezbiterium, ściana południowa. Zaś w literaturze można przeczytać różny tekst sygnatury $\mathrm{z}$ opuszczonym słowem „Picturis” - F. M. S o b i e s z c z a ń s k i, Wiadomości historyczne o sztukach pięknych $w$ dawnej Polsce, t. 2., Warszawa 1849, s. 28; Zaś „Przegląd katolicki” podaje: Sebastian Eckstein adornavit pietnris (!) anno 1747 - „Przegląd Katolicki”, 11 grudnia 1890, nr 50, s. 795. Tutaj błędnie zamiast ,picturis” podano ,pietnris”. Sygnatura jest widoczna na Scenie „Złożenie do grobu”, prezbiterium, ściana południowa. 
się we Lwowie w 1741 r., gdzie samodzielnie wykonał dwa projekty, pierwszy w kościele jezuitów, a drugi w kościele bernardynów. Projekt zrealizowany w Krasnem na zlecenie Błażeja Krasińskiego był jego trzecim samodzielnym projektem (wcześniej prawdopodobnie uczestniczył w pracach swojego ojca w Brnie i na Morawach) ${ }^{89}$.

Ferdynand Łydyński uważa, że w 1880 r., podczas kolejnego remontu kościoła nad nagrobkiem żon Jana Dobrogosta wzniesiono nową ambonę $e^{90}$. Innego zdania jest Anna Frąckowska, według której: „zachowana płyta z figurami pierwotnie znajdowała się w centralnym, reprezentacyjnym miejscu świątyni, na środku prezbiterium, ustawiona na rzeźbionej podstawie wykonanej także z czarnego marmuru. Dopiero ok. 1880 r. przeniesiona została na obecne miejsce"91. W tym wypadku możemy dość precyzyjnie ustalić zmiany jakie zaszły we wnętrzu świątyni w drugiej połowie XIX w. Jest to możliwe dzięki albumowi z fotografiami kościoła wykonanymi w XIX w. Album ten został wydany w kilku egzemplarzach. Artur K. F. Wołosz wspomina o trzech: pierwszy w ADP, drugi w Archiwum Czartoryskich w Krakowie i trzeci który spłonął w czasie II wojny światowej. Jest jeszcze nieznany Wołoszowi egzemplarz, który obecnie znajduje się w parafii kraśnieńskiej, a ponadto kilka zdjęć z niego pochodzących znajduje się w zasobach archiwum Działu Naukowo-Wydawniczego Muzeum Romantyzmu w Opinogórze ${ }^{92}$. Fotografie z 1870 r., ukazują wnętrze kościoła, gdzie ambona znajduje się po lewej stronie nawy głównej (patrząc od wejścia), w połowie jej długości, zaś nagrobek żon Jana Dobrogosta znajduje się również po lewej stronie nawy głównej, na pierwszym przęśle tej nawy, ale nie w prezbiterium jak sądzi Frąckowska. Na fotografiach przedstawiających wnętrze kościoła po remon-

${ }^{89}$ A. B e $t$ l e j, Zapomniany fresk Sebastiana Ecksteina, [w:] Sztuka Kresów Wschodnich, red. A. B e t 1 e j, A. M a r k i e w i c z, Kraków 2012, t. 7, s. 55.

${ }^{90}$ F. Ły d yń s k i, $d z$. cyt., s. 26.

91 A. F r ąc k o w s k a, Nagrobek żon Jana Dobrogosta Krasińskiego w kościele w Krasnem, http://www.wilanow-palac.pl/nagrobek_zon_jana_dobrogosta_krasinskiego _w_kosciele_w_krasnem.html (dostęp 25.07.2018)

$\overline{92}$ Egzemplarz w ADP nr. inw. 73, egzemplarz w Archiwum Czartoryskich nie posiada nr inw. - por. A. K. F. W oło s z, Cymelium ze zbiorów Muzeum Diecezjalnego w Płocku, „Mazowsze”, nr 7 (1996), s. 63. Egzemplarz znajdujący się w parafii kraśnieńskiej również nie posiada nr. inw. W zbiorach archiwum Działu NaukowoWydawniczego MR w Opinogórze są dwie odbitki przedstawiające wnętrza kościoła z $1870 \mathrm{r}$. 
cie przeprowadzonym przez Ludwika Krasińskiego w latach 1877-1883 ambona została przeniesiona nad nagrobek, barierki oddzielające prezbiterium przesunięto za pierwsze przęsło nawy, włączając je tym samym do prezbiterium. Sam nagrobek nie został przesunięty, ale ,położono” go pod kątem na posadzce, tak iż znalazł się pod schodami ambony, zaś przedłużenie prezbiterium poprzez przemieszczenie barierki spowodowało, że nagrobek znalazł się w prezbiterium. Jan Dobrogost Krasiński wybrał na miejsce swojego pochówku Węgrów, który odziedziczył po ojcu. Spoczął tam w kryptach w kościele reformatów, który sam ufundował.

\section{Plebania}

Nic nie wiemy o plebani kanoników regularnych w Krasnem do końca XVIII w. Z akt wizytacyjnych z dnia 27 grudnia 1891 r. dowiadujemy się, że nową plebanię wzniósł w 1779 r. biskup kamieniecki Adam Stanisław Krasiński, który od kasaty swojej diecezji w 1795 r. stale rezydował w Krasnem. Tutaj też zmarł w 1800 r. i został pochowany w podziemiach kościoła. We wspomnianych aktach czytamy: „Pod koniec przeszłego wieku Adam Krasiński Biskup Kamieniecki wybudował tuż przy kościele, szczytem do niego zwrócony dom murowany długości łokci 65 , szerokości 24 , wysokości łokci 5, w którym sam zamieszkał, następnie oddał go na mieszkanie Opatowi Księży Kanoników Laterańskich, miał na dole pokoików II". Z tego fragmentu możemy przypuszczać, że obecna plebania jednak nie pełniła od początku swego istnienia funkcji plebani, ale domu prepozyta, w aktach błędnie nazwanego opatem. Zatem wikariusze musieli mieszkać w innym nieznanym nam domu, prawdopodobnie do 1800 r. mieszkał tam również prepozyt, który po śmierci biskupa kamienieckiego przeniósł się do nowej plebani, która była domem tylko prepozyta. Dalsza część zapisu zdaje się potwierdzać, że dom ten stał się plebanią dla proboszcza i wikarych dopiero w drugiej połowie XIX w.: „Obecny zaś właściciel dóbr miejscowych Ludwik Hr. Krasiński, dom ten przez czas spustoszały z gruntu wyrestaurował i na wygodne mieszkanie proboszcza i wikaryusza oraz służby kościelnej przemienił”. Nie tylko jednoznaczna informacja, że dom wystawiony stał się plebanią dopiero za sprawą Ludwika Krasińskiego w drugiej połowie XIX w. każe domniemywać, że tak faktycznie było, ale także sam rozmiar plebani i jej układ. W Krasnem prepozytura w czasach Jana Dobrogosta Kra- 
sińskiego była obsługiwana przez czterech kanoników, zaś Błażej Krasiński zwiększył obsadę do sześciu.

Tymczasem w dalszej części opisu plebani, w przywoływanych wcześniej aktach wizytacyjnych z dnia 27 grudnia 1891 r., czytamy: „Po lewej stronie od wejścia składa się z kancelaryi i pokoju bawialnego, gościnnego, stołowego wraz z przedpokojem i wyjściem do ogrodu z pokoju dla służących, a po prawej stronie od wejścia ma proboszcz pokój sypialny składający się z przedpokoju, pokoju i alkowy, w pozostałej części plebani z wejściem od szczytu przez pokój duży od frontu przeznaczonym na mieszkanie dla X. Wikarego, dwa zaś mniejsze pokoiki od tyłu przeznaczone na ochronkę, której obecnie nie ma, od tyłu mieści się także kuchnia z zachowankiem. Na górze od szczytu podwórza zajmuje mieszkanie organista, kościelny zaś mieszka w dworskim domu". Wydaje się więc mało prawdopodobne, aby kiedykolwiek mogło tam mieszkać 6 kanoników jednocześnie. Możemy zatem przyjąć, że kanonicy regularni od początku funkcjonowania prepozytury w Krasnem posiadali inny budynek mieszkalny. Możliwe, że kanonicy jako plebanię przejęli mansjonarię, którą ufundował jeszcze Franciszek Krasiński.

Paprocki pisze o fundacji Franciszka Krasińskiego: „W Krasnem (...) Proboszcza, przydawszy mu kilku mensyonarzów, którzy na każdy dzień horaus Beatae Mariae śpiewali, postanowił, szpital i szkołę zmurował i nadał"93. Zatem możliwe, że już od lat siedemdziesiątych XVI w. przy kościele funkcjonował dom mansjonarski, który w XVII w. stał się plebanią kanoników. Zapewne mowa plebania dla kanoników mogła być wzniesiona przez Jana Dobrogosta Krasińskiego, chociaż nie można wykluczyć, że wzniósł ją Jan Kazimierz Krasiński, a przynajmniej rozpoczął budowę, którą ukończył Jan Dobrogost. Nową plebanię planował wznieść Błażej Krasiński, który zwiększył obsadę prepozytury o dwóch kanoników, jednak nie zrealizował swoich zamiarów. Wiemy, że nie zdążył także ukończyć budowy kościoła, m.in. wieży rozebranej do połowy, którą kończono jeszcze 1820 r. $^{94}$, więc jest prawdopodobne, że jego intencją było wzniesienie nowej plebani. Projekt niezrealizowany przez Błażeja Krasińskiego zrealizował biskup kamieniecki Adam Stanisław Krasiński. Możliwe, że realiza-

\footnotetext{
${ }^{93}$ B. P a p r o c k i, dz. cyt., s. 403.

${ }^{94}$ I. G a li c k a, H. S y g i e t yń s k a, dz. cyt., s. 22.
} 
cję projektu rozpoczął on jeszcze przed 1795 r., co prawda od tego roku był stałym rezydentem w Krasnem, ale już od sierpnia 1789 r. uczestniczył w obradach Sejmu Wielkiego, będąc też jednym ze współautorów konstytucji. Zamieszkał wówczas w Warszewie na ul. Miodowej, ale często przebywał w Krasnem. W tym czasie Krasne było własnością jego bratanka i imiennika Adama Krasińskiego. Biskup Krasiński jeszcze za życia podzielił swój majątek pomiędzy bratanków: Jana Krasińskiego, który otrzymał wówczas Opinogórę oraz klucz dunajowiecki i wspomnianego Adama, który otrzymał Krasne. Zdaniem I. Galickiej i H Sygietyńskiej jest prawdopodobne, że autorem projektu, tak samo jak kościoła, był Antoni Solarii, a sam projekt został sporządzony przed rokiem $1763^{95}$. Młynarski analizując przywoływany już tekst ekspensy z 1800 r., uważa, że chodzi tutaj o Bonawenturę Solariego (syna Antoniego) ${ }^{96}$.

Młynarski powołuje się na zapis z archiwum parafialnego w Krasnem gdzie czytamy, odnośnie do budowy plebani 6 maja 1800 r.: „....) Mury w każdym tygodniu robili Mularze pilnujący Abrysu P. Solarego Architekta (...)"97. Gdyby plan był sporządzony ok. 1799 r. Młynarski słusznie wskazywałby na Bonawenturę Solariego, jednak jest wysoce prawdopodobne, o czym była mowa wcześniej, że plan został zamówiony przez Błażeja Krasińskiego jeszcze przed 1751 r., a tylko zrealizowany przez biskupa kamienieckiego w 1799 r., więc przypuszczenie I. Galickiej i H Sygietyńskiej, że autorem projektu plebani był jednak Antoni Solari wydaje się nadal mieć podstawy. Owa plebania funkcjonowała jako rezydencja biskupa kamienieckiego Adama Stanisława Krasińskiego, a po jego śmierci stała się domem prepozyta. Pierwszym prepozytem, który rezydował na plebani wystawionej przez biskupa kamienieckiego był ostatni prepozyt kraśnieński ks. Franciszek Sulima Sułkowski. Po kasacie opactwa czerwińskiego i prepozytury w Krasnem w 1819 r. plebania kanoników stała się zbyteczna. Kanonicy z prepozytury kraśnieńskiej przeszli na wikariaty w diecezji płockiej, a w Krasnem pozostał proboszcz z jednym wikarym. Pierwszym proboszczem, już ekskanonikiem regularnym, był Stanisław Długołecki od 1820 r. do 1829 r., a wikarym od 1821 do 1825 r., był również ekskanonik regularny, ks. Idzi Godlewski. W tej sytuacji dawny dom prepozyta, wyremontowany przez hra-

\footnotetext{
${ }^{95}$ I. G a li c k a, H. S y g i e ty ń s k a, dz. cyt., s. 32.

${ }^{96}$ Ł. P. M $ł$ y n a r s k i, dz. cyt., s. 57.

${ }^{97}$ ADP, Archiwum Parafialne w Krasnem. Odpis 1825, k. XXXV.
} 
biego Ludwika Krasińskiego, zapewne tuż po śmierci w 1879 r. ostatniego ekskanonika regularnego, ks. Idziego Godlewskiego, w zupełności wystarczał na potrzeby proboszcza i wikarego, zaś stara plebania kanoników została rozebrana.

\section{Uposażenie}

O uposażenie prepozytury w Krasnem zadbał jeszcze Jan Kazimierz Krasiński, który w 1668 r. erygował specjalny fundusz na utrzymanie prepozytury kanoników z majątku Poświętne - Zielonki, „na Krasnem dwa półwłóczki w każdym z trzech pól"98 na utrzymanie proboszcza - prepozyta, 4 wikariuszy, organisty, 7 muzyków i zakrystiana, ponadto wyznaczył kanonikom prowadzenie szpitala dla 12 ubogich $^{99}$. Fundacja probostwa i erekcja szpitala dla ubogich w Krasnem została zaakceptowana na sejmie walnym w Warszawie w 1667 r. ${ }^{100}$. Jan Kazimierz, o czym była już mowa, wystawił plebanię dla kanoników regularnych, lub rozpoczął jej budowę. Przy tej okazji po raz pierwszy jest mowa o skarbcu kościoła w Krasnem ${ }^{101}$.

Jan Dobrogost dodał kanonikom regularnym do uposażenia pół wsi Gołymin. Za jego sprawą na sejmie w Warszawie w 1685 r. dokonano reasumpcji fundacji kanoników regularnych. W konstytucjach sejmowych zapisano: „Reassumptio fundacyi Krasieńskiej Canonicorum Regularium. Przywodząc do skutku konstytucyą a. 1667 fyndacyi Probostwa o erekcyi szpitala w Krasnym z dóbr Magnuszewa y Bądkowa, na dobra Gołymin y Obłudzin sumę 60000 złotych Polskich. Ur: Referendarzowi Koronn: novis inscritionibus, coram actis authenticis recongoscentis et per eorum ligamenta transportare pozwalamy et Canonicis Regulares ex consensu Curiae Romanae, locique ordinaris itroductos, przy tejże fundacyi I dobrach, które od wszelkich żołnierskich ciężarów, y hyberyny salvis iednak oneribus Reipublicae et servitio belico in perpetuum uwalniamy y zachowujemy"102. Owe 60 tysię-

\footnotetext{
${ }^{98}$ H. G a w a r e c k i, $d z$. cyt., s. 106.

${ }^{99}$ F. Ł y d y ń s k i, dz. cyt., s. 25.

100 Volumina Legum. Leges, statua, constitutiones et privilegia Regni Poloniae, Magni Ducatus Lithuaniae. t. 4, Petersburg 1860, s. 450 (nr 100).

101 A. K. F. W oło s z, Zaginione złotnictwo ze skarbca w Krasnem, „Mazowsze”, nr 1 (1996), s. 47.

102 Volumina Legum. Leges, statua, constitutiones et privilegia Regni Poloniae, Magni Ducatus Lithuaniae. t. 5, Petersburg 1860, s. 352 (nr 37).
} 
cy złotych polskich zostało zapisane na wsi Gołymin jeszcze przez Jana Kazimierza, a Jan Dobrogost tylko wystarał się o zatwierdzenie nadań poczynionych przez ojca.

Błażej Krasiński, wnuk Jana Dobrogosta, oddał kanonikom regularnym, a właściwie wykupił dla nich od Piotra Górskiego, pozostałą część Gołymina oraz oddał im dochody z Gruduska, Kobylina, Młodzianowa i Obłudzina ${ }^{103}$. Powiększył w 1738 r. obsadę prepozytury o dwóch kanoników i przebudował tamtejszy kościół w latach 1739$1746^{104}$. Prawdopodobnie zamówił u Antoniego Solariego projekt plebani $^{105}$. W 1751 r. zmarł bezpotomnie Błażej Krasiński, wówczas dokonano podziału majątku po zamarłym. Krasne przypadło w udziale Janowi Krasińskiemu i jego synom: Michałowi Hieronimowi Krasińskiemu i Adamowi Stanisławowi Krasińskiemu, wówczas prałatowi gnieźnieńskiemu, a od 1759 r. biskupowi kamienieckiemu. Michał Hieronim i Adam Stanisław ufundowali przed 1756 r. organy do kościoła, wtedy też kościół ponownie konsekrowano. Adam Stanisław Krasiński ufundował przed 1773 r., w stylu rokokowym, ołtarz główny, ambonę i dwa konfesjonały $^{106}$.

Do rozbiorów uposażenie prepozytury w Krasnem składało się z dóbr w Gołyminie wraz z przyległościami, co dawało dochód 111500 złotych polskich, a ponadto sumę 24 tysięcy złotych z Kałęczyna ${ }^{107}$. Po rozbiorach rząd pruski przejął majątek w Gołyminie wypłacając kanonikom co roku odszkodowanie, co było kontynuowane także przez rząd Królestwa Polskiego ${ }^{108}$. W 1819 r. po kasacie prepozytury uposażenie przeszło na własności parafii.

\section{Skarbiec i biblioteka}

Skarbiec kościoła w Krasnem sięga swoimi początkami fundacji biskupa krakowskiego Franciszka Krasińskiego, co potwierdza jego testament z 1577 r., w którym przekazał kościołowi w Krasnem książki

\footnotetext{
${ }^{103}$ H. G a w a re c k i, $d z . c y t$., s. 106-107.

${ }^{104}$ F. Ł y dy ń s k i, dz. cyt., s. 25.

105 I. G a li c k a, H. S y g i e t y ń s k a, dz. cyt., s. 32 .

${ }^{106}$ F. Ł y d y ń s k i, dz. cyt.., s. 25.

${ }^{107}$ H. G a w a re c k i, $d z$. cyt., s. 106-107.

108 Tamże, s. 107.
} 
teologiczne, srebra, szaty liturgiczne ${ }^{109}$. Skarbiec był wzbogacany przez kolejnych Krasińskich kielichami, relikwiarzami, puszkami, monstrancjami. Liczne darowizny do skarbca pochodziły z czasów fundacji prepozytury kanoników w Krasnem za czasów Jana Dobrogosta Krasińskiego ${ }^{110}$. Wiemy, że w 1709 r. waga srebra w argenteriach w skarbcu kościoła w Krasnem wynosiła ponad $62 \mathrm{~kg}^{111}$. Skarbiec był wzbogacony nie tylko darowiznami Krasińskich, ale także innych rodów, a także wzbogacali go sami kanonicy. Prepozyt kraśnieński ks. Franciszek Józef Jagodkowicz, nie tylko fundował srebrną suknie dla obrazu Matki Boskiej w Czerwińsku, ale także ufundował dla kościoła w Krasnem złotą sukienkę na obrazie stygmatyzacji św. Franciszka, prepozyt ks. Jan Żdżarski ufundował srebrna tabliczkę wotywną; srebrna grupa barokowa przedstawiająca: krucyfiks, Matkę Boską, św. Jana oraz dwóch opatów, została prawdopodobnie przekazana z opactwa czerwińskiego do kościoła w Krasnem. Anna Błońska ufundowała dwa kielichy (w 1686 r. i 1688 r.) i kilka tabliczek wotywnych, zaś Marcin Korczakowski ufundował jeden kielich $(1688 \text { r. })^{112}$. Zapis $\mathrm{z}$ testamentu biskupa krakowskiego pozwala nam podejrzewać, że przy kościele w Krasnem znajdował się skarbiec jeszcze przed przebudową rozpoczętą przez Jana Kazimierza Krasińskiego. Wiemy, że początkowo znajdował się na wieży kościoła, która została wystawiana przez Franciszka Krasińskiego, co w połączeniu z informacjami we wspominanym testamencie biskupa krakowskiego pozwala nam domniemywać, że już w 1570 r. funkcjonował skarbiec. Po przebudowie kościoła przeprowadzonej przez Błażeja Krasińskiego w latach 17391746 skarbiec przeniesiono nad zakrystię dobudowaną wówczas do prezbiterium od strony wschodniej ${ }^{113}$. W skarbcu kościoła w Krasnem były przechowywane naczynia liturgiczne nie tylko stanowiące własność prepozytury, ale także będące własnością Krasińskich. W wizytacji z 1817 r. zapisano, że cześć naczyń liturgicznych: „uznane są

109 J. Mu s zy ń ska, Testament biskupa Franciszka Krasińskiego, [w:] Kościót katolicki $w$ Małopolsce $w$ średniowieczu $i$ we wczesnym okresie nowożytnym, red. W. k o w a 1 s k i, J. M u s z y ń s ki, Kielce-Gdańsk 2011, s. 276.

${ }^{110}$ A. K. F. W o ł o s z, dz. cyt., s. 50.

111 Tamże., s. 47.

112 Tamże, s. 50.

113 Tamże, s. 47. 
przez kolatora za kapliczne i należą do Familii»" ${ }^{14}$. Zapis ten wyraźnie wskazuje, że przez cały okres funkcjonowania prepozytury kanoników regularnych $\mathrm{w}$ kościele funkcjonowała kaplica rodowa Krasińskich, w której podczas mszy używano naczyń liturgicznych będących własnością Krasińskich, nie zaś parafii. Jednym z takich przedmiotów przechowywanych w Krasnem był złoty łańcuch biskupa krakowskiego Franciszka Krasińskiego, o którym Władysław Krasiński pisał w 1870 r.: „łańcuch znajdował się w Krasnem, ojcowiźnie księdza Franciszka (...) Szedł spadkiem jako droga pamiątka rodzinna aż do dzisiejszego właściciela hr. Ludwika Krasińskiego, który bibliotece naszej (Ordynacji Krasińskich - przyp. W.J.G.) go ofiarował. Roboty jest prostej, lecz trwalej: w podwójnym lub poczwórnym składzie zawieszony na piersiach, służył zapewne do noszenia krzyża pasterskiego - w codziennem przeto był używaniu (...)"115. Łańcuch zaginał podczas pożogi Biblioteki Ordynacji Krasińskich (BOK) w 1944 r. ${ }^{116}$. Zapewne własne naczynia liturgiczne posiadał także biskup kamieniecki Adam Stanisław Krasiński, który w ostatnich latach życia rezydował w Krasnem.

Ważne miejsce w skarbcu zajmowały relikwie wraz z relikwiarzami. Do najważniejszych relikwii przechowywanych $\mathrm{w}$ kościele kraśnieńskim należą: relikwie Krzyża Świętego umieszczone w krzyżu relikwiarzowym (1668 r.) ze złoconego srebra o wadze 50 grzywien; kolec $\mathrm{z}$ Korony Cierniowej przechowywany $\mathrm{w}$ relikwiarzu w formie monstrancji (ok. 1730 r.) ze złoconego srebra o wadze 5 funtów i 22 łutów; relikwie św. Walentego przechowywane w hermie (ok. 1690 r.) ze srebra o wadze 22 grzywien; relikwie św. Jana Chrzciciela, św. Błażeja i św. Moniki wszystkie umieszczone w jednym krzyżu relikwiarzowym z 2 ćwierci XVII w. wykonanym ze złoconego srebra o wadze 14 grzywien; kości św. Mateusza, przechowywane w relikwiarzu który już w XIX w. był opisywany: „srebrny już zepsuty o czterech liściach, sprawiony przez biskupa Macieja Drzewieckiego" "117. Pochodzenie relikwii Korony Cierniowej jest problematyczne. K. Niesiecki podaje, że relikwie przywiózł z Bazylei Jan Kazimierz

\footnotetext{
114 ADP, Akta wizytacji 1817, [b. syg.], s. 109.

115 W. Krasiński, Wstęp, [w:] Akta Podkanclerskie Franciszka Krasińskiego (1569-1573), cz. 2, wyd. Władysław hr. K r a s i ń s k i, objaśnił Wł. C h o m ę t o w s k i, Warszawa 1870 , s. I.

116 W BOK łańcuch był wpisany pod numerem katalogowym: MOK 1496.

${ }^{117}$ Cytat za: A. K. F. W o ł o s z, dz. cyt., s. 48.
} 
Krasiński. Według Niesieckiego relikwie uratował, przed zniszczeniem skarbca katedry w Bazylei przez ewangelików, mieszczanin od którego relikwie wykupił Jan Kazimierz Krasiński ${ }^{118}$. Jednak wersja przedstawiona przez Niesieckiego, przyjęta przez I. Galicką i H. Sygietyńską $^{119}$, jest nieprawdziwa, a co najmniej wątpliwa. Skarbiec katedry w Bazylei nie ucierpiał podczas reformacji. Kres skarbca nastąpił dopiero w 1833 r. po wojnie domowej, kiedy to podzielono go pomiędzy skłócone półkantony. Część należąca do półkantonu Bazylea-Okręg została sprzedana na aukcji w 1836 r. Wyposażenie skarbca jednak nie zaginęło, ale jest obecnie przechowywane w muzeach ${ }^{120}$. Zbiory przyznane półkantonowi Bazylea-Miasto, trafiły głównie do Muzeum Historycznego, kościoła Świętej Klary w Bazylei i Schweizerisches Landesmuseum w Zurychu. Relikwiarz, w którym obecnie jest przechowywany kolec Korony Cierniowej z Krasnego został ufundowany przez Błażeja Krasińskiego w XVIII w., i pochodzi on z warsztatu angielskiego. Ta wersja wydaje się mieć potwierdzenie w słowach H. Gawareckiego, który pisze: „relikwiarz także srebrny, wyzłacany, w tem iest kolec z korony cierniowej Chrystusa Pana, w flaszecce $\mathrm{z}$ kryształu zapieczętowany, nabyty przez jednego z Krasińskich w Anglii po zmienieniu religii przez ten naród"121. Wersja Gawareckiego o pochodzeniu relikwiarza z Anglii jest bardziej wiarygodna niż Niesieckiego, o pochodzeniu relikwii z katedry w Bazylei.

Wiemy, że w 1806 r. skarbiec, w celu ochrony przed działaniami wojennymi, został przejęty przez hrabiego Wincentego Krasińskiego i, jak ustalił A. K. F. Wołosz, został przewieziony do galicyjskiego majątku Krasińskiego $^{122}$. Wincenty Krasiński zwrócił skarbiec w całości prepozyturze kraśnieńskiej w 1810 r. Wyposażenie skarbca w większości uznano za zaginione, w niewyjaśnionych okolicznościach, w czasie II wojny światowej $^{123}$. Co ciekawe, zajmujący się zagadnieniem A. K. F. Wołosz

\footnotetext{
${ }^{118}$ K. N i e s i e c ki, $d z$. cyt., s. 371.

${ }^{119}$ I. G a li c k a, H. S y g i e t y ń s k a, dz. cyt., s. XVII-XVIII.

${ }^{120}$ Musée National du Moyen Âge w Paryżu, British Museum i Muzeum Wiktorii i Alberta w Londynie, Rijksmuseum w Amsterdamie, Bayerisches Nationalmuseum w Monachium, Kunstgewerbemuseum w Berlinie, Kunsthistorisches Museum w Wiedniu, Ermitaż w Petersburgu, oraz Metropolitan Museum of Art w Nowym Jorku.

${ }^{121}$ H. G a w a r e c k i, $d z$. cyt. s. 103.

122 A. K. F. W oło s z, dz. cyt., s. 48.

${ }^{123}$ Tamże, s. 45-62; I. G a 1 i c k a, H. S y g i e t y ń s k a, dz. cyt., s. XVII-XVIII.
} 
jeszcze w 1996 r. uważał skarbiec za zaginiony, podczas gdy został on odnaleziony w podziemiach kościoła w Krasnem już w 1992 r. podczas remontu $^{124} \mathrm{i}$ w lipcu tego samego roku został przekazany do Muzeum Diecezjalnego w Płocku, gdzie obecnie się znajduje.

Część skarbca kraśnieńskiego, która nie była uważana za zaginioną, dokumentuje Spis obiektów stanowiących wyposażenie kościoła parafialnego $w$ Krasnem ${ }^{125}$ sporządzony w 1972 r. Spośród 67 obiektów ujętych w spisie, z okresu prepozytury w Krasnem (czyli do 1819 r.) znajdują się: organy drewniane rokokowe (pierwsza poł. XVIII w.), chrzcielnica późnobarokowa z czerwonego marmuru, częściowo złocona (pierwsza poł. XVIII w.), 2 feretrony barokowe (XVIII w.), obraz Matki Bożej Szkaplerznej w srebrnej koszuli (XVII w.), obraz św. Franciszka ze srebrną suknią (1694 r.) - dar prepozyta kraśnieńskiego Jagodkowicza, tympanon $\mathrm{z}$ piaskowca późnobarokowy (pierwsza poł. XVIII w.), schodki z płaskorzeźbą aniołka (druga poł XVII w.), kielich srebrny złocony, późnobarokowy (1686 r.), krzyż ołtarzowy, drewno-srebro, barokowy (druga poł. XVII w.), grupa barokowa, srebrna: krucyfiks, Matka Boska, św. Jan, dwóch opatów (druga poł. XVII w.) - prawdopodobnie pochodząca z opactwa czerwińskiego, łódka renesansowa (XVII w.), 6 lichtarzy srebrnych, renesansowych (XVII w.), 3 blachy wotywne srebrne (XVII-XVIII w.), klasycystyczny żyrandol z brązu (1818 r.) - w formie korony, pierwotnie było to nakrycie chrzcielnicy, fundowane przez Marię Urszulę z Radziwiłłów Krasińską, żonę Wincentego Krasińskiego, w 1870 r. było przerobione na żyrandol, obecnie znajduje się w Muzeum Romantyzmu w Opinogórze, 8 ornatów z XVII i XVIII w. - dalej sporządzający spis wymienia velum - jedna sztuka i opana (!) - dwie sztuki, w obu wypadkach chodzi oczywiście o velum quadragesimale, zwane też oponą (nie opaną), czyli tkaniny

\footnotetext{
124 W 1992 r. podczas remontu w kryptach kościoła w Krasnem natrafiono na zamurowaną trumnę, w której był złożony skarbiec. Wszystko wskazuje na to, że skarbiec ukrył ks. Jan Karwowski, który był proboszczem w Krasnem w 1939 r. Ks. Karwowski został zamordowany przez Niemców, stad los skarbca pozostawał nieznany do $1992 \mathrm{r}$.

125 Spis obiektów stanowiących wyposażenie kościoła parafialnego w Krasnem, pow. Ciechanów. Integralna część decyzji nr 515 z dnia 8 czerwca 1972 r. w sprawie wpisania dóbr kultury do rejestru zabytków. Podpisany przez Głównego Konserwatora Zabytków Województwa Warszawskiego W. Kowalczuk-Kochanowski. Jest to załącznik do decyzji o wpisaniu do rejestru zabytków tylko wyposażenia kościoła w Krasnem, sam kościół został wpisany do rejestru zabytków 1 grudnia 1953 r. (A-56) - Archiwum Działu Naukowo-Wydawniczego Muzeum Romantyzmu w Opinogórze.
} 
wielkopostne, kurtyny lub chusty bogato zdobione służące przysłanianiu ołtarzy od piątej niedzieli Wielkiego Postu do Triduum Paschalnego. W Krasnem w 1972 r. zachowały się trzy takie tkaniny, jedna trudna do wydatowania może pochodzić z okresu od końca XVII w. do początku XIX w. i dwie barokowe, jedna z XVII w. i jedna z XVIII w.

W skarbcu znajdowała się także biblioteka parafialna, której początki sięgają, tak jak skarbca, fundacji biskupa krakowskiego Franciszka Krasińskiego, co potwierdza, już przywoływany, jego testament z 1577 r., w którym przekazał kościołowi w Krasnem, oprócz sreber: „ad ecclesiam in Crasne, quam ego sumptibus meis extruxi, księgi wssithkie moie in theologia dla uczenia kapłanów"126. Biblioteka, zawierająca ponad 200 tomów oraz ponad 20 rękopisów przetrwała kasatę kanoników regularnych w 1819 r. i jeszcze do początku lat dziewięćdziesiątych XX wieku znajdowała się w parafii w Krasnem, obecnie jest przechowywana w Bibliotece Wyższego Seminarium Duchownego w Płocku. Ferdynand Łydyński miał dostęp do inwentarza biblioteki sporządzonego w 1877 r., który znajduje się w prywatnych rękach ${ }^{127}$. Wiemy, że biblioteka, która została zapoczątkowana przez biskupa krakowskiego, została wzbogacona także darowizną Jana Krasińskiego (1550-1612), kanonika krakowskiego i gnieźnieńskiego, prepozyta stobnickiego, sekretarza Stefana Batorego. Do biblioteki kraśnieńskiej przekazał m.in.: druki z oficyn bazylejskich na których widnieje złoty odcisk: Joan[es] Krassinski de Krasne Cantor Crac[oviensis] Canonicus Gnesnen[esis] Preposit[us] Stobnicen[is] SRM Secreterius, zdobiony herbem Krasińskich Ślepowron. Jan Krasiński słynął z bogatej biblioteki, wiemy, że nie tylko przekazał ją kościołowi w Krasnem, ale jeszcze za życia obdarował bibliotekę kanoników regularnych na krakowskim Kazimierzu, przekazując jej m.in. czterotomową Biblię wydaną w Lyonie w 1545 r. ${ }^{128}$ opatrzoną

\footnotetext{
${ }^{126}$ J. M u s z y ń s k a, Testament biskupa Franciszka Krasińskiego, [w:] Kościół katolicki $w$ Małopolsce $w$ średniowieczu $i$ we wczesnym okresie nowożytnym, red. W. K o w a 1 s k i, J. M u s z y ń s k i, Kielce-Gdańsk 2011, s. 276.

127 Spis Dziet. Rękopisów, Ksiąg i Akt złożonych w Bibliotece Kościoła $w$ Krasnem i znajdujacych się u Proboszcza a nalezacych do kościoła. Dopetniony $w$ styczniu 1877 roku, rkps. ks. Jana Kochanowskiego - por. F. Ł y d y ń s k i, dz. cyt., s. 26, p. 10.

${ }^{128} \mathrm{~K}$. Ł a t a k, Biblioteka kanoników regularnych laterańskich $w$ Krakowie do końca XVI wieku, „Echa Przeszłości” nr 3 (2002), s. 36. Łatak błędnie podaje, że Jan Krasiń-
} 
tym samym odciskiem co księgi przekazane do biblioteki kościoła w Krasnem ${ }^{129}$. Księgi z biblioteki prepozytury w Krasnem były oznaczone w dwojaki sposób: Bibliotheca Krasnensis ad usum Concionatorum applicatus, Ecclesia Praeposituralis Krasnensis ad usum RR Canonicorum Regularum Lateranus Concionatoris oraz Bibliotheca Crasnensis Canonicorum Regularis Lateranensium ad usum Concionatorum applicatus.

Krasińscy nie tylko fundowali bibliotekę, ale wydaje się, że także pozyskiwali cenne pozycje z biblioteki opactwa czerwińskiego. Wiemy przynajmniej o jednym takim przypadku. Chodzi tu o powstały w skryptorium czerwińskim rękopis z 1488 r., zawierający kopię Tractatus de tentationibus et consolationibus Jakuba z Paradyża kodeks znajdował się przed wojną w Bibliotece Ordynacji Krasińskich w Warszawie, został zniszczony przez Niemców w 1944 r., dzieląc tragiczny los Biblioteki Ordynacji Krasińskich ${ }^{130}$. Nie sposób ustalić, czy rękopis był darem opactwa czerwińskiego dla Krasińskich, czy też został zakupiony przez Krasińskich od kanoników, czy może został przejęty przez Krasińskich z biblioteki zakonnej po kasacie opactwa.

\section{Związki Krasińskich z opactwem czerwińskim}

Krasińscy, jak wiele rodów magnackich, często obierali stan duchowny. Wśród Krasińskich znajdziemy wielu dostojników kościelnych: biskupów, archidiakonów, prałatów i kanoników. Stan zakonny obierały kobiety z rodu Krasińskich, jak np. Cecylia Krasińska, która była wizytką w Warszawie, a w latach 1688-1693 przełożoną wizytek w Krakowie. Zmarła 1693, była córką Stanisława Krasińskiego, kasztelana ciechanowskiego (1644 r.) i płockiego (1658 r.) oraz Barbary z Noskowskich ${ }^{131}$; stan zakonny wybrały także: Aleksandra Krasińska, córka Gabriela (†1676), kasztelana płockiego, bratanica Jana Kazimierza Krasińskiego ${ }^{132}$, która wstąpiła do klarysek w Krakowie; Teofila

ski de Krasne pieczętował się herbem Pobóg, faktycznie pieczętował się herbem Ślepowron.

${ }^{129}$ I. P i e tr z k i e w i c z, Biblioteka kanoników regularnych $w$ Krakowie $w$ XV $i$ XVI, Kraków 2003, s. 48, p. 103.

130 F. P uła s ki, Opis 815 rękopisów Biblioteki Ordynacji Krasińskich, Warszawa 1915, s. 52, sygn. 46 (45).

131 A. B o n i e c k i, dz. cyt., s. 192.

132 Tamże, s. 193. 
Salomea Krasińska (ok. 1680-1758), córka Mikołaja (†1706), kasztelana małogoskiego, była, podobnie jak Aleksandra, klaryską w Krakowie w latach 1692-1758, i ksienią w latach 1726-1741 i 1744-1747 ${ }^{133}$. Także męscy przedstawiciele tego rodu wstępowali do zakonów. Jan Krasiński, syn Mikołaja (†1706), kasztelana małogoskiego, brat Teofilii (klaryski), wstąpił do cystersów. Wiemy także o dwóch wypadkach, gdy Krasińscy wstępowali do zakonu kanoników regularnych. Pierwszym był nieznany z imienia syn Franciszka Krasińskiego zmarłego w 1716 r., którego śmierć odnotowano w liber mortuorum kanoników czerwińskich ${ }^{134}$. Franciszek w liber mortuorum został określony jako palatini Plocensis, a więc wojewoda płocki, tymczasem żaden Franciszek Krasiński nie był wojewodą płockim. Nawet jeżeli przyjąć za Krzysztofem Rafałem Prokopem ${ }^{135}$, że jest to błąd i powinno być palatinidae czyli wojewodzic (syn wojewody), to również niewiele wyjaśnia, ponieważ tylko jeden wojewoda z rodu Krasińskich miał syna Franciszka. Był to Stanisław Krasiński zmarły w 1617 r. Wówczas Franciszek Krasiński, o którym mowa w liber mortuorum czerwińskim byłby bratem Jana Kazimierza i wujem Jana Dobrogosta, ale umierając $\mathrm{w}$ roku 1716 musiałby mieć ok. 100 lat. Wydaje się to jednak mało prawdopodobne. Ponadto dokumenty wskazują, że ten Franciszek Krasiński, sędzia ciechanowski, żonaty z Rylską z Karwic zmarł bezpotomnie ${ }^{136}$.

Drugim kanonikiem regularnym w opactwie czerwińskim był Paweł Krasiński (†1768), o którym wiemy znacznie więcej. Był synem Jakuba Krasińskiego, kasztelana ciechanowskiego zmarłego w 1737 r. i Barbary z Kuklińskich ${ }^{137}$. Paweł był starszym bratem biskupa sufragana chełmskiego Jana Chryzostoma Krasińskiego, zmarłego w 1763 r.

\footnotetext{
133 S. E. S a n de r OSC, S. Teofila Salomea Krasińska, klaryska krakowska (16921758), referat, Ogólnopolska Konferencja Sztuka w kręgu krakowskich franciszkanów i klarysek, 21-23.05.2015, Organizatorzy Instytut Historii Sztuki UJ i Klasztor Ojców Franciszkanów w Krakowie (brak publikacji pokonferencyjnej).

134 „Die 19na Maii. illustrissimi domini Francisci comitis in Krasne, palatini Plocensis, parentis confratris nostri, qui obiit anno 1716to" - K. R. P r o k o p, Staropolskie varia biograficzno-chronologiczne $z$ nowożytnych źródel proweniencji kościelnej (uzupetnienie do kompendiów bio-bibliograficznych $i$ herbarzy), „Biuletyn biblioteki Jagiellońskiej”, nr 66 (2016), s. 188.

135 Tamże.

${ }^{136}$ K. Ni e s i e c ki, $d z$. cyt., s. 368; A. B o n i e c k i, $d z$. cyt., s. 198.

${ }^{137}$ K. N i e s i e c ki, $d z$. cyt., s. 369-370; A. B o n i e c k i, dz. cyt., s. 202.
} 
we Frauenburgu i młodszym bratem Antoniego, cześnika płockiego i kasztelana zakroczymskiego zmarłego w 1762 r. ${ }^{138}$, kuzynem biskupa kamienieckiego Adama Stanisława Krasińskiego. Możliwe, że Paweł Krasiński był prepozytem kraśnieńskim. Nie byłby to pierwszy Krasiński, który był proboszczem w Krasnem. Mikołaj Krasiński (†1575), syn Jana, stolnika ciechanowskiego, swoją karierę zaczynał od probostwa w Krasnem, później był kanonikiem krakowskim i gnieźnieńskim oraz kustoszem łowickim. Liber mortuorum kanoników czerwińskich odnotowuje śmierć Pawła Krasińskiego: „Die 22da Octobris. [Memoria] perillustris admodum reverendi Pauli Korwin de Krasne Krasinski, professi canoniae nostrae, qui obiit Varsaviae ad S. Georgium anno Domini $1768^{\mathrm{vo} " 139}$. Portret Pawła Krasińskiego znajdował się na plebanii w Krasnem jeszcze w latach siedemdziesiątych XX wieku, co odnotowały I. Galicka, H. Sygietyńska ${ }^{140}$. Obecnie portret należy uznać za zaginiony.

Liber mortuorum kanoników czerwińskich odnotowuje także śmierć dobroczyńcy opactwa czerwińskiego i fundatora prepozytury kraśnieńskiej Jana Dobrogosta Krasińskiego: „Die 21 Februarii. [Memoria] illustrissimi domini Joannis Bonaventurae Krasinski, palatini Plocensis, primi et principalis ecclesiae praeposituralis Krasnensis fundatoris nostri, ad quam ecclesiam introduxit canonicos regulares conventus nostri Cervenensis in anno 1681; qui piissimus fundator et benefactor noster obiit anno $1717^{\prime \prime 141}$.

To samo źródło odnotowuje także śmierć syna Jana Dobrogosta Krasińskiego, Stanisława Bonifacego, który zmarł w tym samym roku co ojciec: „Die 9na Januarii. [Memoria] illustrissimi Stanislai Krasinski, castellani Plocensis, capitanei Varsaviensis, Sztumensis, Posnaniensis et fundatoris praepositurae nostrae Krasnensis, qui obiit in Sztum anno $1717 \mathrm{mo"}^{\prime 142}$. Znajdziemy tam także zapis o śmierci żony Stanisława Bonifacego, Marianny z Czarnkowskich oraz zapis o śmierci Damiana Błażeja Krasińskiego. O Michale Władysławie Krasińskim zapisano: „Die 28va Augusti. [Memoria] perillustris reverendissimi domini Mi-

\footnotetext{
138 A. B o n i e c k i, dz. cyt., s. 202.

${ }^{139}$ K. R. P r o k o p, dz. cyt., s. 197.

${ }^{140}$ I. G a li c k a, H. S y g i e t y ń s k a, $d z$. cyt., s. 32. Obecnie obrazu nie ma na plebanii krasnieńskiej jak i w Muzeum Diecezjalnym w Płocku.

${ }^{141}$ K. R. P r o k o p, dz. cyt., s. 188.

142 Tamże, s. 188-189.
} 
chaelis Vladislai Krasinski, olim cancellarii et canonici praepositi collegiatae S. Michaelis et cathedralis ecclesiae Plocensis, post canonici regularis Lateranensis, professi Cervenensis, multorum meritorum viri ac optimi nostri benefactoris, eius enim promotione primum introducti sumus ad praeposituram Krasnensem"143.

\section{Zakończenie}

Prepozytura opactwa czerwińskiego w Krasnem istniała od 1681 r. do 1819 r., a zatem 138 lat, ostatnim jej prepozytem był ks. Franciszek Sulima Sułkowski. Jednak okres bytności kanoników regularnych w Krasnem jest dłuższy, bowiem od objęcia parafii w Krasnem przez pierwszego kanonika regularnego, ks. Franciszka Jagodkowicza 22 stycznia 1681 r. do śmierci ostatniego, już ekskanonika regularnego ks. Idziego Godlewskiego minęło 198 lat. Kościół w Krasnem pozostaje jednym z najciekawszych zabytków architektury sakralnej na Północnym Mazowszu.

\section{Bibliografia}

\section{Źródla}

Archiwum Diecezjalne w Płocku (dalej: ADP), Akta wizytacji archidiakonatu plockiego z 1598-1599 r., syg. 5.

ADP, Akta wizytacji archidiakonatu płockiego z 1609 r. sygn. 5.

ADP, Akta dotyczace stanu diecezji płockiej, sygn. B-2.

ADP, Acta episcopalia (1448-1849), sygn. 46.

ADP, Krasne. Akta wizytacji 1844-1846, [b. syn.].

ADP, Księgi metrykalne w Krasnem. Księga urodzeń 1657-1681, sygn. 529.

ADP, Księgi metrykalne w Krasnem. Księga urodzeń 1681-1710, sygn. 530.

ADP, Krasne, Akta wizytacji 1756-1775, [b. sygn.].

ADP, Akta wizytacji 1817, [b. sygn.].

ADP, Archiwum Parafialne w Krasnem. Odpis 1825, [b. sygn.].

ADP, Kościót w Krasnem (Album), nr inw. 73.

Archiwum Diecezjalne w Drohiczynie, ZAPW, Kontrakt pomiędzy Janem Bonawentura Krasińskim a Carlem Ceronim, sygn. III/Q/1/B.1.

Archiwum Czartoryskich w Krakowie, Kościót w Krasnem (Album), [brak nr inw.].

${ }^{143}$ Cytat za: K. R. Pr o k o p, dz. cyt., s. 197. 
Archiwum Działu Naukowo-Wydawniczego Muzeum Romantyzmu w Opinogórze, Spis obiektów stanowiacych wyposażenie kościoła parafialnego w Krasnem, pow. Ciechanów. Integralna część decyzji nr 515 z dnia 8 czerwca 1972 r. w sprawie wpisania dóbr kultury do rejestru zabytków.

Piasecki P., Praxis episcopalis, Cracoviae 1627.

Volumina Legum. Leges, statua, constitutiones et privilegia Regni Poloniae, Magni Ducatus Lithuaniae. t. 4, Petersburg 1860.

Encyklopedia Kościelna, t. 2, Warszawa 1873.

Obrzędy poświęcenia kościoła i ottarza, wyd. wzorcowe, Katowice 2001, rozdz. III nr 1.

Ordo dedicationis ecclesiae et altaris, Typis Polyglottis Vaticanis 1977.

„Korespondent Płocki”, 5 luty 1880.

„Korespondent Płocki”, 10 czerwca 1886.

„Przegląd Katolicki”, 11 grudnia 1890, nr 50.

\section{Opracowania}

Betlej A., Zapomniany fresk Sebastiana Ecksteina, [w:] Sztuka Kresów Wschodnich, red. A. Betlej, A. Markiewicz, Kraków 2012, t. 7, s. 51-64.

Boberski W., Solari (Solary) Antonio (1700-1763), [w:] Polski Stownik Biograficzny, t. 40, z. 2, 2000, s. 247.

Boniecki A., Herbarz polski, t. 12, cz. 1, Warszawa 1908.

Chlewicka A., Księgozbiór parafialny z Krasnego w świetle XVIII-wiecznych inwentarzy, [w:] W kregu historii i bibliologii. Prace ofiarowane ks. profesorowi Michalowi Marianowi Grzybowskiemu w siedemdziesiata rocznice urodzin, red. Z. Kropidłowski, Bydgoszcz 2007, s. 173-203.

Folwarski H., Poczet opatów klasztoru kanoników regularnych $w$ Czerwińsku, „Nasza Przeszłość”, t. 6 (1959), s. 5-79.

Frąckowska A., Nagrobek żon Jana Dobrogosta Krasińskiego w kościele w Krasnem, http://www.wilanow-palac.pl/nagrobek_zon_jana_dobrogosta krasinskiego_w_kosciele_w_krasnem.html (dostęp 25.07.2018)

Galicka I., Sygietyńska H., Ciechanów i okolice, [w:] Katalog zabytków sztuki w Polsce. T. 10, [Województwo warszawskie], z. 1, Warszawa: Instytut Sztuki PAN, 1977.

Gawarecki H., Pamiętnik historyczny płocki, t. 2. Warszawa 1830.

Góralski W., Diecezja płocka i jej synody w okresie potrydenckim, „Studia Płockie", t. 14 (1986), s. 159-186.

Góralski W., Reforma organizacji dekanalnej w diecezji płockiej za bpa Andrzeja Chryzostoma Załuskiego w 1693 r. „Studia Płockie”, t. 12 (1984), s. $109-120$.

Górczyk W. J., Reformaci w Wegrowie. Architektura kościoła i miejsce fundacji węgrowskiej na tle działalności fundacyjnej Krasińskich, „Drohiczyński Przegląd Naukowy”, nr 10 (2018), s. 307-326. 
Górczyk W. J., Kościót reformatów w Wegrowie fundacji wojewody płockiego, starosty przasnyskiego, Jana Dobrogosta Krasińskiego herbu Slepowron, „Notatki Płockie”, nr 1 (2018), s. 13-21.

Górczyk W. J., Pomniki nagrobne biskupa krakowskiego Franciszka Krasińskiego i wojewody płockiego Stanistawa Krasińskiego, „Muzealne Rozmaitości”, nr 1 (2018), s. 10-11.

Górczyk W. J., Biskup kamieniecki Adam Stanisław Krasiński (1714-1800). Szkic do studium biograficznego, „Bieżuńskie Zeszyty Historyczne”, nr 31 (2017), s. 62-98.

Grzybowski M. M., Idzi Godlewski (1793-1879), [w:] Tenże, Duchowieństwo diecezji płockiej, t. 3, Płock 2012, s. 90-91;

Kowalczyk A., Biblioteka kanoników regularnych w czerwińsku, „Notatki Płockie", nr 1 (2009), s. 3-10.

Lato Z., Troska salezjanów o ośrodki kultu maryjnego $w$ Polsce $w$ latach 1989-1988, „Seminare. Poszukiwania Naukowe”, nr 14 (1998), s. 147-169.

Łatak K., Biblioteka kanoników regularnych laterańskich $w$ Krakowie do końca XVI wieku, „Echa Przeszłości”, nr 3 (2002), s. 27-47.

Łydyński F., Dzieje kościoła w Krasnem, „Mazowsze”, nr 7 (1996) s. 25-30.

Masiak W., Krasne- Krasińscy-Opinogóra, Warszawa 1975.

Młynarski Ł. P., Kościót i mauzoleum Krasińskich $w$ Krasnem $w$ okresie nowożytnym. Przyczynek do dziejów obiektu, [w:] Franciszka z Krasińskich Wettyn, red. D. Kalina, R. Kubicki, M. Wardzyński, Kielce-Lisów 2012, s. 53-63.

Muller A., Diecezja płocka od drugiej połowy XVI wieku do rozbiorów, „Studia Płockie", nr 3 (1975), s. 153-226.

Muszyńska J., Testament biskupa Franciszka Krasińskiego, [w:] Kościót katolicki $w$ Małopolsce $w$ średniowieczu $i$ we wczesnym okresie nowożytnym, red. W. Kowalski, J. Muszyński, Kielce-Gdańsk 2011, s. 283-294.

Niesiecki K., Herbarz Polski, wyd. J. N. Bobrowicz, t. 5, Lipsk 1840,

Nowiński J., 400 lat obecności cudownego obrazu Matki Bożej Pocieszenia (Matki Bożej Czerwińskiej) na Jasnej Górze w Czerwińsku, „Seminare”, nr 33 (2013), s. 319-338.

Paprocki B., Herby rycerstwa polskiego, zebrane $i$ wydane r. p. 1584, wyd. K. J. Turowski, Kraków 1858.

Pietrzkiewicz I., Biblioteka kanoników regularnych w Krakowie w XV i XVI, Kraków 2003.

Prokop K. R., Staropolskie varia biograficzno-chronologiczne z nowożytnych źródet proweniencji kościelnej (uzupetnienie do kompendiów biobibliograficznych $i$ herbarzy), „Biuletyn biblioteki Jagiellońskiej”, nr 66 (2016), s. 177-214.

Przyboś A., Krasiński Jan Dobrogost, [w:] Polski Słownik Biograficzny, t. 15, Wrocław- Warszawa- Kraków 1970, s. 180-182. 
Przyłubska D., Nagrobek Andrzeja i Katarzyny Krasińskich w kościele w Krasnem, „Mazowsze”, nr 7 (1996), s. 37-44.

Pułaski F., Opis 815 rękopisów Biblioteki Ordynacji Krasińskich, Warszawa 1915.

Samsonowicz H., Freski Sebastiana Ecksteina w kościele w Krasnem, „Mazowsze”, nr 7/(1996) s. 31-36.

Wołosz A. K. F., Cymelium ze zbiorów Muzeum Diecezjalnego w Płocku, „Mazowsze”, nr 7 (1996), s. 63-64.

Wołosz A. K. F., Zaginione złotnictwo ze skarbca w Krasnem, „Mazowsze”, nr 7 (1996), s. 45-62.

Żebrowski T., Kościót (XIV-początek XVI w.), [w:] Dzieje Mazowsza, t. 1, Pułtusk 2006, s. 447-487.

\section{WOJCIECH JERZY GÓRCZYK}

\section{PREPOZYTURA KANONIKÓW REGULARNYCH LATERAŃSKICH W KRASNEM NA MAZOWSZU (1681-1819), FUNDACJI KRASIŃSKICH HERBU ŚLEPOWRON}

Streszczenie: Prepozytura kanoników regularnych laterańskich w Krasnem na Mazowszu, w ziemi ciechanowskiej, rodowym gnieździe Krasińskich herbu Ślepowron, została utworzona w 1681 r. Kościół będący siedzibą prepozytury, którego początki sięgają XIV w., został przebudowany przez Jana Kazimierza Krasińskiego (ur. 1607 r., zm. 28 marca 1669 r.), który rozpoczął starania, aby uczynić z niego prepozyturę opactwa czerwińskiego kanoników regularnych laterańskich i Jana Dobrogosta Krasińskiego (ur. 10 czerwca 1639 r., zm. 21 lutego 1717 r.), który uskutecznił zabiegi ojca, dając początek prepozyturze. Od tej pory parafia w Krasnem, która jest wzmiankowana po raz pierwszy pod datą 1443 r., przeszła w ręce kanoników regularnych laterańskich. Pierwszym prepozytem w Krasnem został 22 stycznia 1681 r. kanonik regularny laterański ks. Franciszek Jagodkowicz. Wśród kanoników regularnych z opactwa czerwińskiego znajdujemy także Pawła Krasińskiego (†1768), który zapewne był także prepozytem kraśnieńskim. Prepozytura w Krasnem funkcjonowała do 1819 r., kiedy to uległo kasacie opactwo czerwińskie. Ostatnim prepozytem kraśnieńskim był ks. Franciszek Sulima Sułkowski. Jednak okres bytności kanoników regularnych w Karsnem jest dłuższy, bowiem od objęcia parafii w Krasnem pierwszego kanonika regularnego do śmierci ostatniego, już ekskanonika regularnego, ks. Idziego Godlewskiego, który był proboszczem w Krasnem od 1855 r., minęło 198 lat. Kościół w Krasnem pozostaje do dzisiaj jednym z cenniejszych zabytków architektury sakralnej na Północnym Mazowszu.

Slowa kluczowe: Jan Dobrogost Krasiński, Jan Kazimierz Krasiński, Węgrów, Czewińsk, opactwo. 


\title{
THE PREPOSITURE OF CANONS REGULAR OF THE LATERAN IN KRASNE IN MAZOVIA (1681-1819), FOUNDATION OF THE KRASIŃSKI FAMILY OF THE ŚLEPOWRON COAT OF ARMS
}

\begin{abstract}
The Prepositure of Canons Regular of the Lateran in Krasne in Mazovia, in the Ciechanów land, the Krasiński family nest of the Ślepowron coat of arms, was created in 1681 . The seat of the prepositure - a church dating back to the $14^{\text {th }}$ century, was rebuilt by Jan Kazimierz Krasiński (born in 1607, deceased on March 28, 1669), who made efforts to make it the prepositure of the Czerwińsk Abbey of Canons Regular of the Lateran and Jan Dobrogost Krasiński (born on June 10, 1639, deceased on February 21, 1717), who put his father's efforts into effect, initiating the creation of the prepository. From then on, the parish in Krasne, first mentioned in 1443, passed into the hands of Canons Regular of the Lateran. The first provost in Krasne, Fr. Franciszek Jagodkowicz CRL, was appointed on January 22, 1681. Among the Canons Regular of the Czerwińsk Abbey, we also find Paweł Krasiński († 1768), who most probably was also a provost. The prepositure in Krasne existed until 1819, when the Czerwińsk Abbey was dissolved. The last provost of Krasne was Fr. Franciszek Sulima Sułkowski. However, the Canons Regular of the Laterans stayed in Krasne for the overall period of 198 years: from taking over the parish in Krasne by the first Canon Regular, until the death of the last ex-Canon Regular, Fr. Idzi Godlewski, the provost of Krasne since 1855. The church in Krasne remains to this day one of the most valuable monuments of sacred architecture in northern Mazovia.
\end{abstract}

Keywords: Jan Dobrogost Krasiński, Jan Kazimierz Krasiński, Węgrów, Czerwińsk, abbey. 